\title{
Statistical assessment of nonpoint source pollution in agricultural watersheds in the Lower Grand River watershed, MO, USA
}

\author{
Fadhil K. Jabbar ${ }^{1,2}$ (D) Katherine Grote ${ }^{1}$ \\ Received: 28 February 2018 / Accepted: 5 November 2018 / Published online: 14 November 2018 \\ (C) The Author(s) 2018
}

\begin{abstract}
The water quality in many Midwestern streams and lakes is negatively impacted by agricultural activities. Although the agricultural inputs that degrade water quality are well known, the impact of these inputs varies as a function of geologic and topographic parameters. To better understand how a range of land use, geologic, and topographic factors affect water quality in Midwestern watersheds, we sampled surface water quality parameters, including nitrate, phosphate, dissolved oxygen, turbidity, bacteria, $\mathrm{pH}$, specific conductance, temperature, and biotic index (BI) in 35 independent sub-watersheds within the Lower Grand River Watershed in northern Missouri. For each sub-watershed, the land use/land cover, soil texture, depth to bedrock, depth to the water table, recent precipitation area, total stream length, watershed shape/relief ratio, topographic complexity, mean elevation, and slope were determined. Water quality sampling was conducted twice: in the spring and in the late summer/early fall. A pairwise comparison of water quality parameters acquired in the fall and spring showed that each of these factors varies considerably with season, suggesting that the timing is critical when comparing water quality indicators. Correlation analysis between water quality indicators and watershed characteristics revealed that both geologic and land use characteristics correlated significantly with water quality parameters. The water quality index had the highest correlation with the biotic index during the spring, implying that the lower water quality conditions observed in the spring might be more representative of the longer-term water quality conditions in these watersheds than the higher quality conditions observed in the fall. An assessment of macroinvertebrates indicated that the biotic index was primarily influenced by nutrient loading due to excessive amounts of phosphorus $(\mathrm{P})$ and nitrogen $(\mathrm{N})$ discharge from agricultural land uses. The PCA analysis found a correlation between turbidity, E. coli, and $\mathrm{BI}$, suggesting that livestock grazing may adversely affect the water quality in this watershed. Moreover, this analysis found that $\mathrm{N}, \mathrm{P}$, and SC contribute greatly to the observed water quality variability. The results of this study can be used to improve decisionmaking strategies to improve water quality for the entire river basin.
\end{abstract}

Keywords Agricultural pollution · Nutrients $\cdot$ Surface water quality $\cdot$ Lower Grand River Watershed $\cdot$ Biotic index $\cdot$ Statistical analysis $\cdot$ PCA

\section{Introduction}

Nonpoint source (NPS) pollution from agricultural activities has become the main source of contamination in surface water

Responsible editor: Philippe Garrigues

Fadhil K. Jabbar

fkj5gd@mst.edu

1 Department of Geosciences and Geological and Petroleum Engineering, Missouri University of Science and Technology, McNutt Hall, 1400 N. Bishop Ave, Rolla, MO 65401, USA

2 College of Science, University of Misan, Amarah, Iraq in the USA. In much of the US Midwest, agriculture was identified as the most likely source to cause impairment in the assessed rivers and streams (USEPA 2013). The primary pollutants from agricultural activities are excessive inputs of nutrients through commercial fertilizer and manure (Ahearn et al. 2005; Fournier et al. 2017; Chen et al. 2017; Kourgialas et al. 2017), runoff from pesticides and herbicides (Hildebrandt et al. 2008; Sangchan et al. 2013; Cruzeiro et al. 2015), and increased turbidity due to soil erosion (Zhang and Huang 2014). The most problematic nutrients are phosphorus $(\mathrm{P})$ and nitrogen $(\mathrm{N})$, which are often carried into streams through overland flow during rainfall events (Driscoll et al. 2003; Maillard and Santos 2008; Kato et al. 2009; Mouri et al. 2011; Yu et al. 2015), especially before the 
growing season and after harvest (Zhu et al. 2012). Excessive inputs of nutrients, such as nitrogen and phosphorus, to surface water can contribute to eutrophication, excessive algal growth, increased toxicity, and other adverse influences on fish and aquatic invertebrate communities (Xu et al. 2013; Wang and Tan 2017). Generally, all types of agricultural practices and land use, including animal feeding operations (AFOs), are treated as agricultural NPS pollution. NPS pollution depends on hydrological conditions and is difficult to measure or control directly. However, due to the features of NPS pollution, field measurements, and the limitations of experiments, NPS pollution management practices depend on spatial-temporal simulation modeling, a key method used to estimate NPS pollution related to spatial uncertainty (Shamshad et al. 2008; Huiliang et al. 2015). Various approaches have been used to estimate the loads of NPS pollution, including small spatial-scale experiments and watershedscale modeling, which accurately calculates the pollution loads of different land uses through experimental methods (Alberti et al. 2007; Pratt and Chang 2012). Thus, the methods used in field experimental methods are too time-intensive and expensive to translate into practical applications (Liang et al. 2008). Furthermore, it is difficult to extend field experimental methods to the watershed scale due to the biological and chemical reactions and the complexity of the transport mechanism in the watershed.

Some research has tried to investigate the impacts of land use and land cover on surface water quality (Haidary et al. 2013; Huang et al. 2015). The relationship between land cover and water quality has been studied to reveal the effects of the characteristics of watersheds on the dissolved oxygen (DO) turbidity and river temperature (Li et al. 2015). Other research analyzed the watershed scale in addition to using remotely sensed data and GIS as well as multivariate analysis to estimate the influence of the land cover on the nutrients, suspended sediments, and ecological integrity of rivers (Lai et al. 2011; Exner-Kittridge et al. 2016). For example, when studying largely forested watersheds in North Carolina, Potter et al. (2005) applied simple regression and stepwise regression to develop relationships between eight independent variables (derived from land use/land cover (LULC) and landform characteristics) and the macroinvertebrate index. Schoonover and Lockaby (2006) and Rothenberger et al. (2009) used a similar method to develop correlations between LULC parameters (e.g., percent of impervious surface, mixed forest, evergreen forest, and pasture) and quality parameters (e.g., nutrient and bacteriological characteristics) for watersheds in the USA. Because a large number of variables are required to describe water quality and the factors that affect it, multivariate statistical analysis has become a powerful tool to investigate and interpret the results. Among the multivariate analysis approaches, principal component analysis (PCA) has been widely used to determine how different reaches of a stream contributes to the overall pollution load (Kannel et al. 2007; $\mathrm{Bu}$ et al. 2010; Olsen et al. 2012) or which parameters are most crucial in calculating the water quality index (WQI) (Sharma and Kansal 2011; Koçer and Sevgili 2014; Zeinalzadeh and Rezaei 2017). Furthermore, PCA analysis can also illustrate how the variability of water quality properties changes with time (Ouyang et al. 2006; Jung et al. 2016).

Therefore, this study builds upon the results of previous research by developing correlations in a large number (35) of independent watersheds with mixed LULC (including forest, pasture, row crops, and urban areas) and investigating which combinations of LULC, geologic, and topographic properties are most predictive of both the physicochemical water quality parameters and the biotic index. The independent variables in these relationships are readily available GISbased parameters. Although similar or more accurate results can be obtained using surface water models, such as the Soil and Water Assessment Tool or BASINS, these models require more sophisticated or temporally variable inputs than the relationships developed in this study, and thus, are much more difficult to implement.

The primary objectives of this study are to provide relationships that can be used with readily available GIS databases and ArcGIS tools to indicate which watersheds have the combination of characteristics most likely to result in poor water quality, to assess regionally variability in water quality parameters both spatially and temporally, and to determine which water quality characteristics have the greatest impact on aquatic health. Scientists and regulators can use these results to inform sampling campaigns or to identify areas where more sophisticated modeling is appropriate.

\section{Methods and materials}

\section{Site background}

This study was conducted in the Lower Grand River Watershed, located in north-central Missouri and southcentral Iowa (Fig. 1). The drainage area of the Lower Grand River Watershed is about $6112 \mathrm{~km}^{2}$, and the Grand River drains into the Missouri River as it exits this watershed. This watershed was chosen because it is representative, in terms of land use, geomorphology, and geologic characteristics, of many watersheds in the southern parts of the US Midwest. Thus, statistical correlations derived from this watershed may be applied to other regional watersheds with similar land use. The primary land use in the Lower Grand River Watershed is agricultural. About $48 \%$ of the watershed is used for pasture or hay, and $27 \%$ is used for cultivated crops, primarily corn, soybeans, and wheat. Approximately $13 \%$ percent of the land is forest, and 5\% is urban. The topography of the Lower Grand River Watershed is fairly flat, with an 


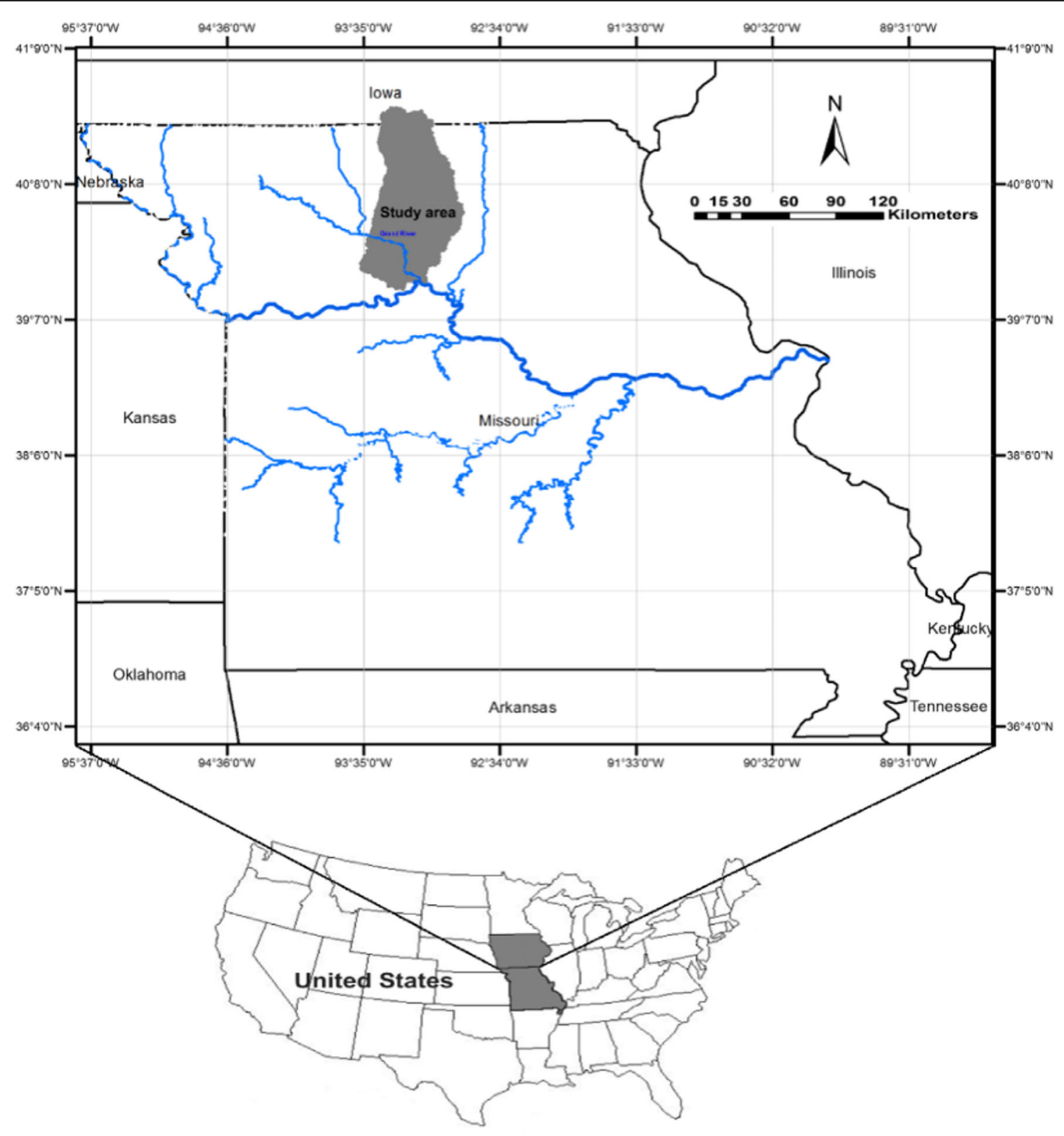

Fig. 1 The location of the Lower Grand River Watershed

average slope of $8^{\circ}$, as shown in Fig. 2a. Most of the study area is covered with Quaternary deposits of glacial drift and alluvium that are less than $30.5 \mathrm{~m}$ thick (Fig. 2b) (Gann et al. 1973). Soils in the study area are mostly loam, with loam, clay loam, and silt loam being the most common soil textures (Fig. 2c). Throughout the study area, the soils tend to be fertile and easily erodible (Detroy and Skelton 1983). The bedrock is primarily Pennsylvanian-age shale and limestone, with incised channels filled with sandstone (Vandike 1995).

According to the Midwestern Regional Climate Center (MRCC 2016), the average annual precipitation in the watershed ranges from $1029 \mathrm{~mm}$ in the north to $1054 \mathrm{~mm}$ in the south. The greatest volume of precipitation occurs in May and June, and stream discharge is highest during these months and lowest during the late summer and fall (USDA-SCS 1982). Since soil permeability is relatively low, most rainfall runs off into streams rather than infiltrating the groundwater, and streams typically exhibit rapid increases in discharge after precipitation, but quickly return to low flow conditions after surface runoff has stopped (MDNR 1984).

Surface water quality in the Lower Grand River Watershed is variable. According to Missouri Section 303(d), about 25\% of the total length of the rivers and streams in the study area are listed as impaired (MDNR 2016). The most common types of known impairments are Escherichia coli (E. coli) contamination, high concentrations of phosphorus and nitrogen, high total suspended soils, and low DO (USEPA 2016; MDNR 2016). These impairments seem to be primarily a result of 


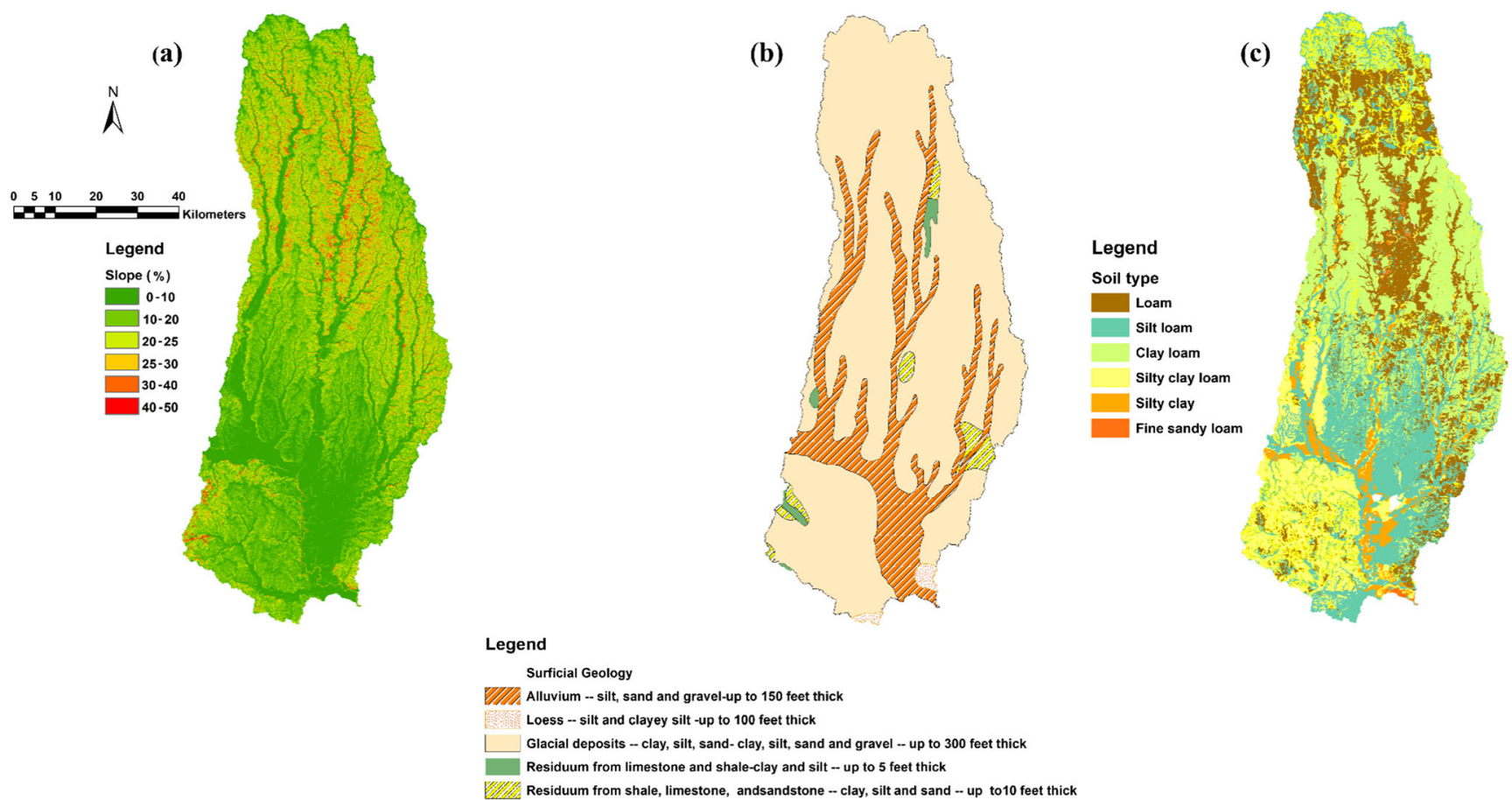

Fig. 2 Characteristics of the Lower Grand River Watershed. a Percent slope. b Soil origin and thickness. c Soil texture

agricultural activities, although urban activities can also contribute to surface water degradation in the few watersheds with more development. Wilkison and Armstrong (2015) studied the impact of commercial fertilizers in the Lower Grand River Watershed, finding that the average application rates of agricultural chemicals, such as phosphorus and nitrogen, in this watershed have approximately doubled during the last four decades.

\section{Data acquisition and processing}

The Lower Grand River Watershed has been divided into 64 sub-watersheds, as defined by the US Geological Survey (USGS) hydrologic unit code HUC12-digit watersheds. Many of these sub-watersheds contain perennial streams that drain into the Grand River, although some sub-watersheds have intermittent streams (MDNR 2014). For this study, the geologic and LULC characteristics were determined for each of the 35 independent subwatersheds in the Lower Grand basin, where an independent watershed is defined as one that receives no inflow from another watershed. Sampling was performed near the mouth of each sub-watershed (Fig. 3).

Surface water sampling was conducted in two major campaigns, in the late summer/fall of 2016 and spring of 2017 , to monitor the streams after and before the primary growing season. For the late summer 2016 campaign, data were collected from 32 sub-watersheds over three weekends, August 3-4, September 11-12, and September 2829. Three additional sub-watersheds were investigated, but the streams were dry. Relatively little precipitation occurred in the 2 weeks preceding data acquisition in the late summer/fall; the average precipitation in the 2 weeks preceding these campaigns was $1.87 \mathrm{~mm}$ (1.37 mm, $2.48 \mathrm{~mm}$, and $1.75 \mathrm{~mm}$, for the first, second, and third weekends, respectively). All precipitation measurements were calculated as the arithmetic average of the precipitation measured by eight rain gauges located within or adjacent to the study area, as shown in Fig. 3. Precipitation data were downloaded from the National Oceanic and Atmospheric Administration Climate Data database (NOAA 2017). In the spring 2017, data were acquired from 35 sub-watersheds on April 2-3 and April 9-10. More precipitation was received before the spring data collection; the average for the preceding 2 weeks before each campaign was $3.72 \mathrm{~mm}$ (2.74 and 4.71, for the first and second weekends, respectively). The stream discharge during each sampling campaign reflected the differences in precipitation. The average discharge of all the sampled streams during the late summer/fall was $3.6 \mathrm{~m}^{3} / \mathrm{s}$, while the average discharge in the spring was $95 \mathrm{~m}^{3} / \mathrm{s}$.

Although little precipitation occurred in the few weeks prior to data acquisition, the 3 months of 2016 preceding the late summer/fall field campaign were approximately $26 \%$ wetter than average (i.e., average precipitation from July to September in 2006 through 2017 was $317 \mathrm{~mm}$, while in 2016, it was $401 \mathrm{~mm}$ ). This above-average precipitation may influence water quality by increasing baseflow above normal levels, although the streams 


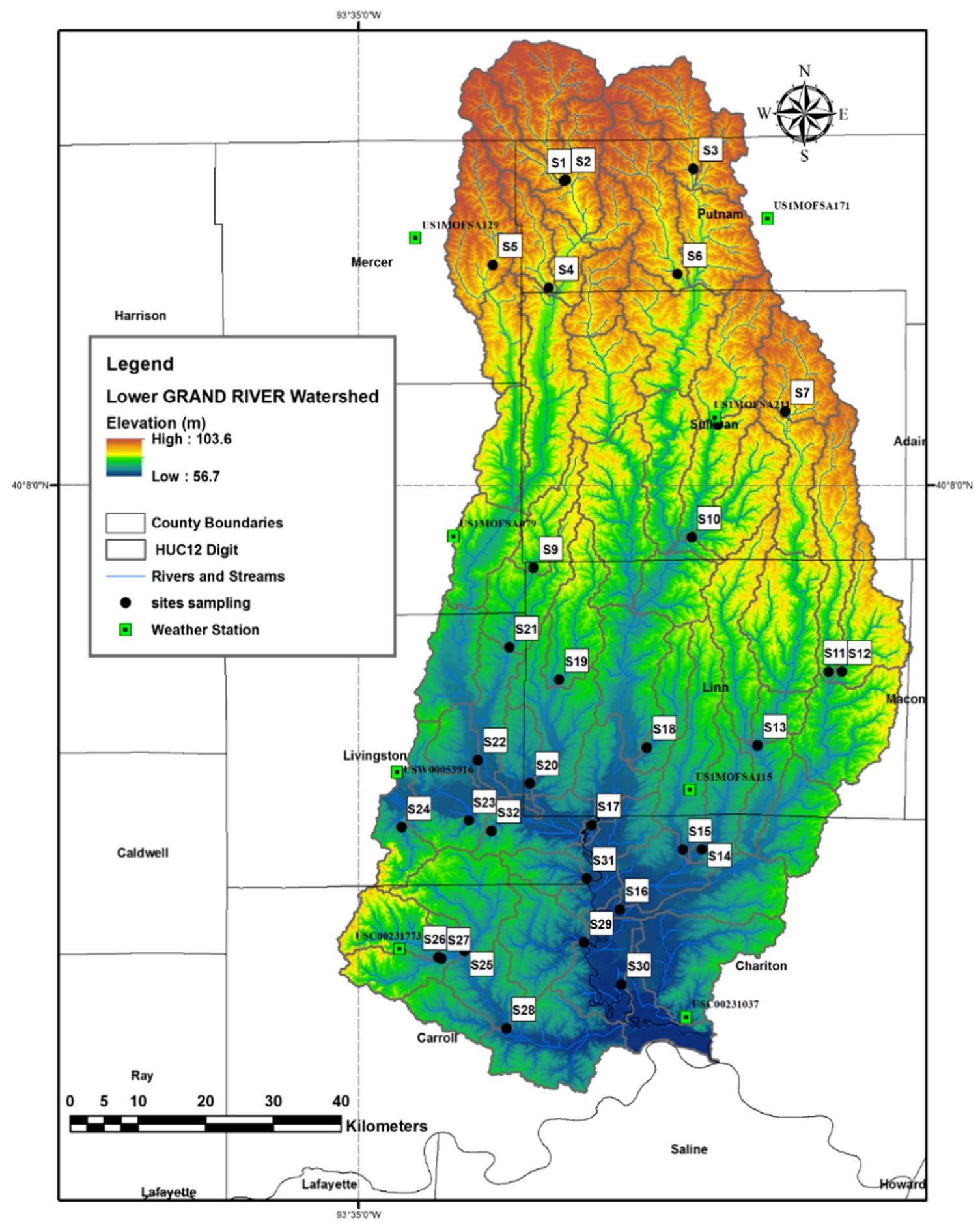

Fig. 3 Map of the Lower Grand River Watershed showing HUC12-digit sub-watersheds, sampling locations, and precipitation stations

monitored were mostly quite small and seemed more influenced by short-term (within the past few weeks) precipitation than by longer-term precipitation, as seen in the measured discharges. During the spring campaign, precipitation was close to average; average precipitation from February to April in 2006 through 2017 was $219 \mathrm{~mm}$, while in 2017 , the precipitation over these 3 months was $223 \mathrm{~mm}$.

\section{GIS data processing}

Data from remote sensing and field mapping techniques are available in a geographic information system (ArcGIS) database maintained by the Missouri Spatial Data Information Service (MSDIS) (n.d.). Figure 2 shows the slope, soil origin, and soil texture for the study area, as provided by the MSDIS. ArcGIS 10.2 was used to determine the values of the 
parameters for each of the 35 sub-watersheds. Some parameters, such as soil texture, LULC classification, depth to bedrock, depth to the water table, watershed area, and stream length, were obtained as shapefiles from the MSDIS. Other information, such as slope, topographic complexity, watershed shape index, watershed slope/relief ratio, and mean elevation, was derived from a 30-m resolution digital elevation model (DEM) provided by the MSDIS. ArcGIS was also used to analyze the data and to determine the average values of each parameter for each sub-watershed, as shown in Table 1.

LULC data were also analyzed using ArcGIS. The National Land Cover Database 2011 (Homer et al. 2015) includes 15 LULC categories (Fig. 4a). To reduce the number of independent variables and to create more meaningful LULC categories for this study, some of these categories were combined. All categories labeled "developed" were combined into one "urban" classification, and all categories labeled "forest" were combined into one group. Similarly, "wetland" categories were combined (Fig. 4b).

\section{Precipitation}

To better understand how recent precipitation affects water quality parameters, the depth of precipitation was also estimated for each sub-watershed. To obtain the most accurate precipitation information, ground-based rain gauge data were used instead of satellite data. Precipitation depth was calculated as the sum of all precipitation that occurred in a 2-week period prior to data acquisition at the rain gauge station closest to each drainage basin. Since rain gauge data are not available for each sub-watershed, the precipitation value is an estimate based on the closest available data.

\section{Water quality parameters}

\section{Data acquisition}

Surface water samples were collected from 32 sub-watersheds in August and September 2016 and from 35 sub-watersheds in April 2017. Fewer samples were collected in the fall 2016 because some streams were dry. Some water quality parameters were acquired in situ, including temperature, $\mathrm{pH}, \mathrm{SC}$, and DO, all of which were measured with a YSI ProPlus multimeter. Turbidity was also measured in the field using a Hach $2100 \mathrm{Q}$ portable turbidimeter. Samples were acquired in the field and tested for bacteria, phosphate $(\mathrm{P})$, and nitrate $(\mathrm{N})$ in the laboratory. All field measurements and samples were acquired using standard USGS procedures, including equipment calibration twice a day, cleansing of all equipment between samples, and following standard procedures to avoid contamination (USGS 2006). P and N samples were filtered on site and collected in sterilized polypropylene bottles. When needed, sulfuric acid was added to the $\mathrm{N}$ samples for preservation, if the samples could not be analyzed within $24 \mathrm{~h}$ of

Table 1 Minimum, maximum, mean, and standard deviation for independent variables

\begin{tabular}{|c|c|c|c|c|c|}
\hline Variable & Description & Minimum & Maximum & Mean & Std. deviation \\
\hline Area $\left(\mathrm{km}^{2}\right)$ & Area of watershed & 42.4 & 141.0 & 95.2 & 28.5 \\
\hline Watershed shape index & Area/square of watershed length & 0.1 & 1.55 & 0.37 & 0.26 \\
\hline Average slope & & 1.97 & 7.28 & 4.35 & 1.51 \\
\hline Total stream length $(\mathrm{km})$ & Total stream length in watershed & 11.2 & 78.7 & 36.3 & 13.2 \\
\hline Topographic complexity & Standard deviation of elevation within watershed & 12.90 & 47.7 & 28.9 & 11.2 \\
\hline Watershed slope/relief ratio $(\mathrm{m} / \mathrm{km})$ & $\begin{array}{l}\text { Watershed elevation change/watershed length } \\
\text { from outlet to highest point on perimeter }\end{array}$ & 2.3 & 7.8 & 4.2 & 1.7 \\
\hline Mean elevation (m) & Mean elevation of watershed & 215.7 & 306.3 & 250.1 & 23.8 \\
\hline Urban $(\%)$ & Percent of watershed & 2.72 & 10.9 & 4.6 & 1.44 \\
\hline Forest $(\%)$ & Percent of watershed & 3.2 & 28.90 & 12.4 & 5.60 \\
\hline Pasture/hay (\%) & Percent of watershed & 16.3 & 74.24 & 51.2 & 17.71 \\
\hline Cultivated crops $(\%)$ & Percent of watershed & 3.6 & 66.9 & 24.9 & 16.5 \\
\hline Wetland $(\%)$ & Percent of watershed & 0.34 & 23.5 & 4.1 & 6.3 \\
\hline Clay + silt $(\%)$ & Percent of clay and silt content & 52.8 & 79.05 & 63.7 & 4.8 \\
\hline Average depth to groundwater (m) & & 3.05 & 11.7 & 7.17 & 2.01 \\
\hline Average depth to bedrock (m) & & 8.6 & 56.9 & 35.5 & 12.6 \\
\hline Discharge $\left(\mathrm{m}^{3} / \mathrm{s}\right)$ (measured in field) - fall & & 0.0085 & 0.95 & 0.16 & 0.22 \\
\hline Discharge $\left(\mathrm{m}^{3} / \mathrm{s}\right)$ (measured in field)—spring & & 0.81 & 23.94 & 2.7 & 4.36 \\
\hline Precipitation $(\mathrm{mm})$ fall & & 0.00 & 19.05 & 2.46 & 5.83 \\
\hline Precipitation (mm) spring & & 45.7 & 92.4 & 65.8 & 19.8 \\
\hline
\end{tabular}




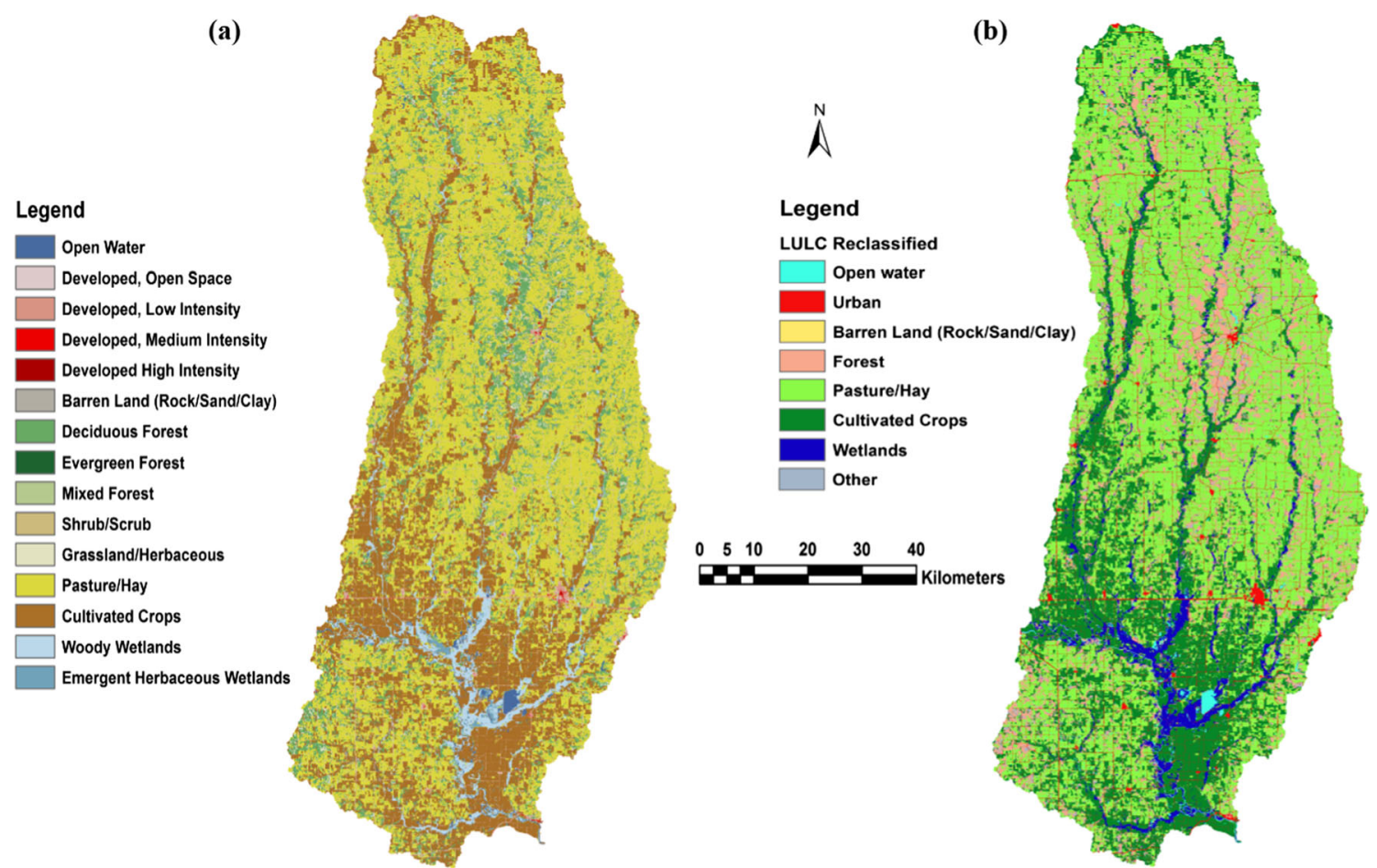

Fig. 4 Land use categories a before reclassification and $\mathbf{b}$ after reclassification and aggregated into eight categories

collection. Sample bottles were rinsed three times with stream water from the sampling sites before the samples were collected. Bacteria samples were collected in sterilized Whirl-Pak® bags. All samples were preserved on ice during transportation and refrigerated at $4{ }^{\circ} \mathrm{C}$ until they were processed. Bacteria samples were processed within $8 \mathrm{~h}$ of data collection, and $\mathrm{N}$ and $\mathrm{P}$ samples were processed within $24 \mathrm{~h}$, except for a few $\mathrm{N}$ samples that were preserved with acid and processed within $48 \mathrm{~h}$.

Laboratory procedures were based on manufacturers' recommendations. Bacteria samples were processed using Coliscan ${ }^{\circledR}$ Easygel ${ }^{\circledR}$, and samples were analyzed after $24 \mathrm{~h}$ of incubation for $E$. coli concentrations. $\mathrm{N}$ and $\mathrm{P}$ (orthophosphate) were analyzed using a Hach DR 3900 spectrophotometer. $\mathrm{N}$ concentrations were analyzed using the chromotropic acid method (Hach Method 10020), where $\mathrm{N}$ reacts with chromotropic acid to change the color of the solution, with a maximum absorbance at $410 \mathrm{~nm}$. Soluble reactive $\mathrm{P}$ concentrations were analyzed using ascorbic acid (HACH standard procedure 8048). In this process, the $\mathrm{P}$ in the sample reacted with ammonium molybdate to form a phospho-molybdate complex, which then reacted with the ascorbic acid reagent to change the color of the solution. For both $\mathrm{N}$ and $\mathrm{P}$, the concentrations were determined by measuring the intensity and wavelengths of light passing through the sample after reaction with the powder-pillow reagents.

Because water quality can change quickly with time, macroinvertebrate analysis was performed to assess the average water quality over a longer time period than was used for the water chemistry measurements (Paulsen et al. 2008; Buss and Vitorino 2010; Mereta et al. 2013; LópezLópez and Sedeño-Díaz 2014; Van Ael et al. 2015; Gezie et al. 2017). Aquatic macroinvertebrates were acquired and identified using the bioassessment protocol for Missouri (MDNR 2003). The macroinvertebrates were collected using a $1000-\mu \mathrm{m}$ kick net placed in the downstream section of a riffle zone. A 1-m by 1-m area immediately upstream of the net was disturbed by vigorous shuffling in the streambed. For sites that did not contain riffles, the net was placed downstream of a root mat, and the area around and underneath the root mat was disturbed. The net was then lifted, and macroinvertebrates were removed from the net, identified to the lowest taxonomic level (generally, genus), and counted. All remaining macroinvertebrates were placed into a sample jar and preserved with $80 \%$ ethyl alcohol for more rigorous identification in the laboratory. In general, macroinvertebrate collection was performed at two locations within each site. As macroinvertebrate collection at each site was very time-intensive, macroinvertebrates were acquired only during the fall 2016 and only at 16 sites.

Stream discharge was determined using standard USGS procedures. Each stream was divided into 20 evenly spaced intervals, and the water velocity and depth were measured at the center of each interval. A USGS Pygmy Meter Model 6205 was used to measure velocity. Stream discharge was calculated as the sum of the velocity, depth, and width for each interval, for all intervals of the product. 


\section{Summary of water quality parameters}

To assess stream health based on macroinvertebrate populations, the biotic index (BI) was calculated (Eq. 1). The BI is based on the classification of macroinvertebrates depending on their tolerance of pollution and was calculated for each site using

$B I=\sum_{i=1}^{s} \frac{T V_{i} N_{i}}{N_{t}}$

where $S$ is the number of taxa in the sample, $T V_{i}$ is the pollution tolerance value of the $i$ th taxon, $N_{i}$ is the density of the $i$ th species taxon as abundance (numbers per square meter), and $N_{t}$ is the total number of macroinvertebrates in the sample (Lenat 1993). Tolerance values range from 0 (highly intolerant) to 10 (highly tolerant) and were chosen for each taxon using the protocol developed by Sarver (2005), which is applicable to this study area. The BI is also scored from 0 to 10 (Table 2), with 0 indicating generally excellent water quality and 10 indicating generally very poor water quality (Hilsenhoff 1988).

Stream health can also be assessed using the water quality index (WQI) (Eq. 2), which was calculated using the method developed by Cude (2001). The WQI is based on the subindex measurements of $\mathrm{pH}$, temperature, DO, biochemical oxygen demand, nitrate, total phosphorus, total dissolved solids, and fecal coliform. It provides a summary of water quality, ranging from 0 (very poor) to 100 (excellent) (Kaurish and Younos 2007; Ramos et al. 2016).

$W Q I=\sum_{i=1}^{n} S I_{i} W_{i}$

where $W Q I$ is the water quality index, $S I$ is sub-index $i$, and $\mathrm{W}_{i}$ is the weight given to sub-index $i$.

\section{Statistical data analysis}

Statistical analyses were performed using the Statistical Package for Social Sciences (SPSS) software. The water quality parameters were first analyzed using the Cunnane

Table 2 Biotic index and pollution levels

\begin{tabular}{lll}
\hline Biotic index & Water quality rating & Degree of organic pollution \\
\hline $0.00-3.5$ & Excellent & No apparent organic pollution \\
$3.51-4.5$ & Very good & Slight organic pollution possible \\
$4.51-5.5$ & Good & Some organic pollution probable \\
$5.51-6.5$ & Fair & Fairly substantial pollution likely \\
$6.51-7.5$ & Fairly poor & Substantial pollution likely \\
$7.51-8.5$ & Poor & Very substantial pollution likely \\
$8.51-10.0$ & Very poor & Severe organic pollution likely \\
\hline
\end{tabular}

probability method to determine if they were normally distributed at $\alpha=0.01$. The critical correlation coefficients for the fall $(n=32)$ and spring $(n=35)$ data sets were 0.950 and 0.954 , respectively. Some factors were normally distributed without any transformations, but others required transformation. Various transforms were tried (e.g., logarithmic, natural $\log$, square root, and cubed root), and the transform with the highest correlation coefficient $(R)$ (closest to the normal distribution) was applied in all further analyses. If the data were normally distributed without a transformation, no transformation was performed. All parameters were normally distributed either before or after transformation.

Six analyses were performed on the water quality data. First, the standard parametric summary statistics were calculated for each variable. Next, a pairwise comparison was performed for each water quality variable acquired in the spring and fall. The differences for each characteristic were calculated, and the Cunnane method was again employed to determine whether the differences were normally distributed. If the differences were normal, the paired $t$ test was employed to determine if the two data sets were statistically different. If the differences were not normal, the sign test was used. The third analysis was a simple linear regression between each independent variable (i.e., LULC, geologic, or topographic parameters) and each dependent variable (i.e., water quality parameter) to determine the strength and direction of the correlation between each pair of variables. The fourth analysis was a stepwise linear regression to determine which independent variables were most useful for predicting water quality parameters. The partial $F$ entry test and partial $F$ removal test had a significance level of $\alpha=0.05$. The coefficient of multiple determination $\left(R^{2}\right)$ for each regression equation indicates the proportion of the variability in the water quality parameters that can be explained by the independent variable. The fifth analysis compared the biotic index values with the WQI to determine how well the biotic index predicted the WQI. The final analysis was a principal component analysis of the physicochemical water quality variables and the BI.

\section{Results}

\section{Summary statistics of water quality parameters}

Summary statistics for each of the water quality parameters measured in this experiment are shown in Table 3 . This table shows that significant variations in water quality occurred between watersheds within each data campaign and that some parameters varied significantly between data campaigns. Temperature was much higher during the fall than during the spring, which indicates that the streams probably had a larger proportion of surface runoff compared to baseflow during the fall. Temperature was also more variable during the fall, which 
may be related to the generally lower discharge during this season, as smaller streams are more susceptible to changes in air temperature. Two of the least variable parameters were $\mathrm{pH}$ and $\mathrm{P}$, with relatively little variation between watersheds or with season. SC showed significant variations between watersheds, but relatively little variation with season. DO was significantly higher during the spring, perhaps due to increased turbulence in the streams, associated with higher discharge. Turbidity, N, and E. coli counts, all of which would be expected to increase with increasing overland flow, had much higher values during the spring.

\section{Pairwise comparison of fall and spring data}

Table 4 shows the pairwise comparisons for each water quality parameter that was acquired in both the fall and spring. The fall and spring data sets were statistically different, with fairly low $p$ values for all water quality parameters. This suggests that temporally variable factors influencing these parameters may be more important than static factors in estimating surface water quality.

\section{Simple regression}

Simple regression analysis was done between all water quality indicator variables and all independent variables (i.e., LULC, geologic, and topographic factors). For water quality characteristics that were not normal before transformation (i.e., turbidity, N, $\mathrm{P}$, and $E$. coli), the transformed (square root) data were used for the correlation analysis. The correlation coefficient (Pearson's coefficient or $R$ ) and the statistical significance of each regression relationship is shown for the most significant correlations between water quality variables and the independent variables in Tables 5 and 6 for the fall and spring, respectively. These tables illustrate that the independent variables that best correlate with water quality indicators vary with season for some water quality indicators but remain more temporally consistent with others. During the fall, the independent variable that correlated most often with water quality was the "pasture/hay" land use category; this land use was significant for N, P, E. coli, and turbidity. Since pasture includes land where livestock graze, it is probable that these water quality parameters are affected by animal waste and/or erosion created by animals near streambanks (Walters et al. 2011). The percent of urban land also correlated with multiple water quality parameters, including $E$. coli, $\mathrm{P}$, and temperature. The Lower Grand watershed is predominantly rural, but several sub-watersheds include developed areas. Leaching from septic tanks, municipal sewage, lawn fertilizers or urban stormwater runoff may impact streams. Although the fall was relatively dry, the second most frequently observed independent variable was precipitation, which was the most significant factor related to $\mathrm{N}$ and SC. These correlations suggest that even small amounts of precipitation can be significant for transporting nutrients and other dissolved solids to surface water (Narasimhan et al. 2010; Jeznach et al. 2017). DO correlated best with the geologic factors of depth to bedrock and depth to groundwater, while temperature and $\mathrm{pH}$ had only weak or statistically insignificant correlations.

The spring data exhibited many of the same independent factors correlated to water quality parameters along with several new correlations. Unlike in the fall, cultivated crops had more effect, being significantly correlated with $\mathrm{N}, \mathrm{SC}$, and temperature. This effect might result from the timing of fertilizer application because approximately twice as much fertilizer is applied near planting time in the spring than during the fall in Missouri (Fulhage 2000; Missouri Agricultural Experiment Station 2014). The composition of the fertilizer is also significant, as approximately four times as much nitrogen is applied in the spring as in the fall, but the amount of

Table 3 Summary statistics of water quality parameters for two sampling campaigns

\begin{tabular}{|c|c|c|c|c|c|c|c|c|}
\hline \multirow[t]{2}{*}{ Variable } & \multicolumn{4}{|l|}{ Fall } & \multicolumn{4}{|l|}{ Spring } \\
\hline & Minimum & Maximum & Mean & Std. deviation & Minimum & Maximum & Mean & Std. deviation \\
\hline $\mathrm{T}\left({ }^{\circ} \mathrm{C}\right)$ & 16.10 & 28.60 & 21.55 & 3.62 & 10.10 & 15.40 & 12.3 & 1.53 \\
\hline $\mathrm{pH}$ & 7.13 & 8.35 & 7.77 & 0.40 & 7.65 & 8.75 & 8.26 & 0.32 \\
\hline DO (mg/L) & 0.30 & 9.51 & 3.48 & 2.38 & 4.65 & 11.18 & 9.10 & 1.85 \\
\hline $\mathrm{SC}(\mu \mathrm{s} / \mathrm{cm})$ & 205.60 & 605.00 & 307.34 & 99.28 & 150.00 & 461.90 & 271.74 & 78.84 \\
\hline Turbidity (NTU) & 4.33 & 219.00 & 47.64 & 54.59 & 17.50 & 428.00 & 94.88 & 89.5 \\
\hline Phosphate (mg/L) & 0.12 & 13.43 & 1.12 & 3.28 & 0.19 & 10.38 & 0.74 & 1.70 \\
\hline Nitrate $(\mathrm{mg} / \mathrm{L})$ & 0.10 & 21.60 & 1.77 & 5.29 & 0.64 & 18.80 & 2.78 & 3.16 \\
\hline E. coli $(\mathrm{cfu} / 100 \mathrm{~mL})$ & 100.0 & 1350.0 & 509.37 & 347.47 & 0.00 & 4550.00 & 1012.85 & 1245.78 \\
\hline Biotic index (BI) & 4.0 & 7.42 & 5.35 & 1.02 & & & & \\
\hline WQI & 51.63 & 84.65 & 66.30 & 8.43 & 42.67 & 85.56 & 68.73 & 8.86 \\
\hline
\end{tabular}




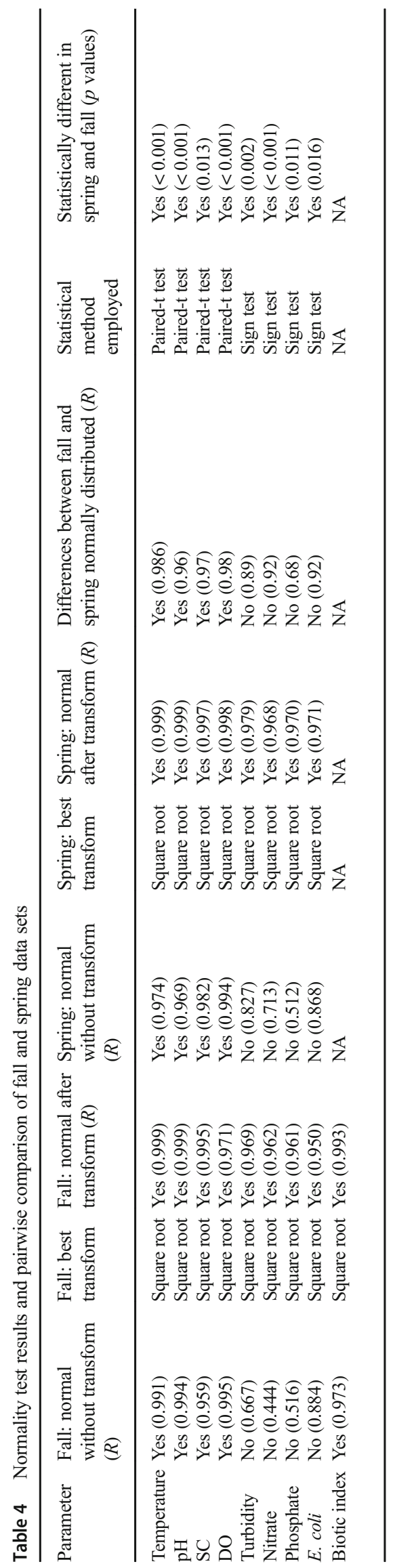

phosphatic fertilizer is approximately equal in the spring and fall (Missouri Agricultural Experiment Station 2014). The percentage of land classified as urban was less significant during the spring, when only E. coli correlated with this parameter.

An evaluation of regression coefficients indicates that only some of the factors most highly correlated with water quality indicators are seasonal. This variability is probably due to changes in the proportion of surface runoff and baseflow in streams. Geologic factors, such as depth to groundwater and slope as well as LULC factors correlated strongly with water quality indicators. This means that topographic and geologic factors cannot be neglected when determining the watersheds with the greatest risk of water quality impairment.

\section{Stepwise multiple regression}

Stepwise multiple regression was performed to determine which independent variables were most suitable for predicting water quality indicators in different seasons. Stepwise regression only employs independent variables that significantly improve the correlation after other independent variables are considered. For example, slope and topographic complexity may both correlate strongly with water quality, but these independent variables are often correlated. Therefore, it is not useful to include them both in a regression equation because it would not greatly improve the estimation of a water quality indicator. In addition, it would add unnecessary complexity to the relationship and make data acquisition more arduous. Consequently, the only parameters included in the following stepwise regression equations are those that most significantly and independently improve the correlation to water quality indicators. As with the correlation analysis, water quality parameters that were not normal before transformation were transformed prior to regression, but those that were normally distributed without a transformation were not transformed. Table 7 displays the stepwise regression results for the fall, while Table 8 presents similar results for the spring.

Table 7 shows that during the fall, a statistically significant regression equation could be generated for each of the water quality indicators, but the quality of these predictions (as shown by the $R^{2}$ value) was often low. The parameters where more than $50 \%$ of the variance could be predicted using regression relationships were temperature, $\mathrm{DO}, \mathrm{SC}$, and biotic index. In some cases, the independent variables in the regression equation were the same as those with high correlation coefficients in Table 5; however, other water quality indicators were best predicted by variables without the highest correlation. For the stepwise regression relationships with higher Pearson coefficients, geologic parameters (e.g., depth to bedrock, depth to groundwater, soil type) were often more helpful for predicting water quality indicators than were LULC characteristics. For several of the relationships with lower Pearson coefficients, precipitation was the most significant variable, 
Table 5 Correlation coefficients between water quality indicators and watershed landscape characteristics during the fall

\begin{tabular}{|c|c|c|c|c|c|c|c|c|}
\hline Factor of correlation & $R$ & $p$ value & Factor of correlation & $R$ & $p$ value & Factor of correlation & $R$ & $p$ value \\
\hline \multicolumn{3}{|l|}{ DO } & \multicolumn{3}{|l|}{$\mathrm{pH}$} & \multicolumn{3}{|l|}{ Temperature } \\
\hline Average depth to bedrock (m) & 0.72 & 0.000 & Discharge $\left(\mathrm{m}^{3} / \mathrm{s}\right)$ & -0.15 & 0.25 & Urban\% & 0.53 & 0.05 \\
\hline Average depth to groundwater (m) & 0.52 & 0.006 & & & & & & \\
\hline \multicolumn{3}{|l|}{$\mathrm{SC}$} & \multicolumn{3}{|c|}{ Escherichia coli (E. coli) } & \multicolumn{3}{|l|}{ Turbidity } \\
\hline \multirow[t]{3}{*}{ Precipitation (mm) } & -0.47 & 0.012 & Urban\% & 0.37 & 0.045 & Clay + silt $\%$ & 0.63 & 0.000 \\
\hline & & & Pasture/hay\% & 0.37 & 0.05 & Pasture/hay\% & 0.58 & 0.005 \\
\hline & & & & & & Average slope & 0.54 & 0.001 \\
\hline Nitrate & & & Phosphate & & & Biotic index (BI) & & \\
\hline Precipitation (mm) & 0.6 & 0.013 & Urban $\%$ & 0.4 & 0.031 & Turbidity (NTU) & 0.58 & 0.008 \\
\hline Pasture/hay\% & 0.40 & 0.03 & Pasture/hay\% & 0.33 & 0.03 & Phosphate (mg/L) & 0.47 & 0.031 \\
\hline
\end{tabular}

suggesting that the timing of a measurement may strongly influence the result.

During the spring (Table 8), the regression relationships often had lower Pearson coefficients than during the fall. Only temperature and SC had relationships where more than $50 \%$ of the variability could be explained by the correlation variables. As with the fall, geologic or topographic parameters had a greater effect than LULC variables, although urban land use was significant for $E$. coli and $\mathrm{P}$, and pasture/hay was important for $\mathrm{N}$.

A comparison of stepwise regression relationships developed using data acquired during the spring and fall show that for approximately half of the water quality parameters (e.g., temperature, E. coli, pH, DO, and turbidity), one independent variable occurs in the regression equation for both seasons. However, the relationships developed using the spring data present differing (usually additional) independent variables. The independent variable that remains significant across both seasons tends to be the most critical predictor for each water quality indicator. For some water quality indicators, such as
$\mathrm{SC}, \mathrm{N}$, and $\mathrm{P}$, the independent variables in the regression relationships differ completely depending on season. This suggests that the loading mechanisms for these parameters may vary significantly with season and recent land use modifications, such as fertilizer application, so different seasonal models may be required to predict water quality using simple stepwise regression relationships.

\section{Water quality and biotic indexes}

The results of the WQI are shown in Fig. 5. The fall WQI values ranged from 52 (very poor) to 97 (excellent), while WQI values during the spring ranged from 43 (very poor) to 86 (very good). During the spring, about $70 \%$ of the watershed sites were degraded. The lower WQI in the spring might have been caused by increased surface runoff that carried recently applied nutrients, sediment, and bacteria to the streams.

The WQI value is based on several physicochemical water quality parameters and bacterial concentration. These parameters may change with time and are difficult

Table 6 Correlation coefficients between water quality indicators and watershed landscape characteristics during the spring

\begin{tabular}{|c|c|c|c|c|c|c|c|c|}
\hline Factor of correlation & $R$ & $p$ value & Factor of correlation & $R$ & $p$ value & Factor of correlation & $R$ & $p$ value \\
\hline DO & & & $\mathrm{pH}$ & & & Temperature & & \\
\hline $\begin{array}{l}\text { Average depth to groundwater } \\
\text { (m) }\end{array}$ & 0.55 & 0.000 & $\begin{array}{l}\text { Average depth to groundwater } \\
\text { (m) }\end{array}$ & 0.60 & 0.000 & Pasture/hay\% & 0.62 & 0.000 \\
\hline Precipitation $(\mathrm{mm})$ & 0.30 & 0.040 & Clay + silt $\%$ & 0.47 & 0.02 & Cultivated crops $\%$ & 0.60 & 0.000 \\
\hline $\mathrm{SC}$ & & & Escherichia coli (E. coli) & & & Turbidity & & \\
\hline Average slope & 0.70 & 0.000 & Urban\% & 0.41 & 0.003 & Discharge $\left(\mathrm{m}^{3} / \mathrm{s}\right)$ & 0.50 & 0.001 \\
\hline Average depth to bedrock (m) & -0.55 & 0.000 & Pasture/hay\% & 0.3 & 0.043 & Average slope & 0.37 & 0.013 \\
\hline Cultivated crops $\%$ & 0.54 & 0.000 & & & & & & \\
\hline Nitrate & & & Phosphate & & & Biotic index & & \\
\hline Pasture/hay\% & 0.40 & 0.012 & Pasture/hay\% & 0.43 & 0.031 & Nitrate (mg/L) & 0.52 & 0.019 \\
\hline \multirow[t]{2}{*}{ Cultivated crops $\%$} & 0.30 & 0.020 & Precipitation (mm) & 0.40 & 0.040 & Phosphate (mg/L) & 0.45 & 0.040 \\
\hline & & & & & & Turbidity (NTU) & 0.30 & 0.012 \\
\hline
\end{tabular}


Table 7 Stepwise regression models between water quality indicators and watershed landscape characteristics during the fall

\begin{tabular}{|c|c|c|c|c|}
\hline & Beta coefficients & $R$ & $R^{2}$ & $p$ value \\
\hline \multicolumn{5}{|l|}{ Model for temperature } \\
\hline Average depth to bedrock & -0.07 & 0.84 & 0.70 & 0.000 \\
\hline Total stream length & 0.13 & & & \\
\hline \multicolumn{5}{|l|}{ Beta coefficients $($ constant $)=26.4$} \\
\hline \multicolumn{5}{|c|}{ Regression equation: Temperature $=26.4-0.07$ (average depth to bedrock) +0.13 (total stream length) } \\
\hline \multicolumn{5}{|c|}{ Models for E. coli } \\
\hline Urban & 3.6 & 0.56 & 0.32 & 0.006 \\
\hline \multicolumn{5}{|c|}{ Beta coefficients $($ constant $)=-10.4$} \\
\hline \multicolumn{5}{|c|}{ Regression equation: $E$. coli $=3.6$ (urban) -10.4} \\
\hline \multicolumn{5}{|c|}{ Model for $\mathrm{pH}$} \\
\hline Precipitation & -0.18 & 0.32 & 0.10 & 0.000 \\
\hline \multicolumn{5}{|l|}{ Beta coefficients $($ constant $)=8.44$} \\
\hline \multicolumn{5}{|c|}{ Regression equation: $\mathrm{pH}=8.44-0.18$ (precipitation) } \\
\hline \multicolumn{5}{|c|}{ Model for DO } \\
\hline Average depth to bedrock & 0.04 & 0.72 & 0.52 & 0.007 \\
\hline Average depth to groundwater & 0.1 & & & \\
\hline \multicolumn{5}{|l|}{ Beta coefficients $($ constant $)=-3.2$} \\
\hline \multicolumn{5}{|c|}{ Regression equation: $\mathrm{DO}=-3.2+0.04$ (average depth to bedrock) +0.1 (average depth to groundwater) } \\
\hline \multicolumn{5}{|l|}{ Model of turbidity } \\
\hline Average slope & -0.25 & 0.64 & 0.4 & 0.002 \\
\hline Urban & -3.41 & & & \\
\hline \multicolumn{5}{|l|}{ Beta coefficients $($ constant $)=119.7$} \\
\hline \multicolumn{5}{|c|}{ Regression equation: Turbidity $=119.7--0.25$ (average slope) -3.41 (urban) } \\
\hline \multicolumn{5}{|l|}{ Model of SC } \\
\hline Precipitation & 11.06 & 0.83 & 0.70 & 0.002 \\
\hline Clay + silt & 4.3 & & & \\
\hline \multicolumn{5}{|c|}{ Beta coefficients $($ constant $)=-309.4$} \\
\hline \multicolumn{5}{|c|}{ Regression equation: $\mathrm{SC}=-341.73+11.06$ (precipitation $)+4.3($ clay + silt $)$} \\
\hline \multicolumn{5}{|l|}{ Model for nitrate } \\
\hline Precipitation & 0.46 & 0.53 & 0.28 & 0.001 \\
\hline Urban & 0.37 & & & \\
\hline \multicolumn{5}{|l|}{ Beta coefficients $($ constant $)=-1.1$} \\
\hline \multicolumn{5}{|c|}{ Regression equation: Nitrate $=0.46$ (precipitation $)+0.37$ (urban $)-1.1$} \\
\hline \multicolumn{5}{|c|}{ Model for phosphate } \\
\hline Precipitation & 0.07 & 0.57 & 0.32 & 0.02 \\
\hline \multicolumn{5}{|l|}{ Beta coefficients $($ constant $)=0.57$} \\
\hline \multicolumn{5}{|c|}{ Regression equation: Phosphate $=0.57+0.07$ (precipitation) } \\
\hline \multicolumn{5}{|l|}{ Model for biotic index (BI) } \\
\hline Turbidity & 0.3 & 0.88 & 0.78 & 0.002 \\
\hline Urban & -0.9 & & & \\
\hline Temperature & 0.14 & & & \\
\hline Beta coefficients $($ constant $)=4.2$ & & & & \\
\hline Regression equation: $\mathrm{BI}=0.3(\mathrm{t}$ & -0.9 (urban) +0.14 & rature) & & \\
\hline
\end{tabular}

to measure on a continuous basis. Macroinvertebrate populations are more time-consuming to sample in the field but can provide information about average water quality over time. Figure 6a compares the WQI and biotic index for the fall data, displaying the expected trend between these variables; however, the correlation is too low to meaningfully relate these two parameters. Figure $6 \mathrm{~b}$ presents the biotic index data acquired in the fall with the WQI calculated using water quality measurements collected in the spring. Even though these data sets were acquired at 
Table 8 The stepwise regression models between water quality indicators and watershed landscape characteristics during the spring

\begin{tabular}{|c|c|c|c|c|}
\hline & Beta coefficients & $R$ & $R^{2}$ & $p$ value \\
\hline \multicolumn{5}{|l|}{ Model for temperature } \\
\hline Average slope & 1.2 & 0.78 & 0.61 & 0.000 \\
\hline Watershed slope/relief ratio & -0.57 & & & \\
\hline Average depth to bedrock & -0.01 & & & \\
\hline \multicolumn{5}{|l|}{ Beta coefficients $($ constant $)=11.8$} \\
\hline \multicolumn{5}{|c|}{$\begin{array}{l}\text { Regression equation: Temperature }=11.8+1.2 \text { (average slope })-0.57 \text { (watershed slope/relief ratio) }-0.01 \\
\text { (average depth to bedrock) }\end{array}$} \\
\hline \multicolumn{5}{|l|}{ Model for $E$. coli } \\
\hline Urban & 4.3 & 0.60 & 0.36 & 0.001 \\
\hline \multicolumn{5}{|l|}{ Beta coefficients $($ constant $)=24.5$} \\
\hline \multicolumn{5}{|c|}{ Regression equation: $E$. coli $=4.3$ (urban) +24.5} \\
\hline \multicolumn{5}{|c|}{ Model for $\mathrm{pH}$} \\
\hline Average depth to groundwater & 0.03 & 0.67 & 0.46 & 0.002 \\
\hline Precipitation & 0.005 & & & \\
\hline \multicolumn{5}{|l|}{ Beta coefficients $($ constant $)=7.03$} \\
\hline \multicolumn{5}{|c|}{ Regression equation: $\mathrm{pH}=7.03+0.03$ (average depth to groundwater) +0.005 (precipitation) } \\
\hline \multicolumn{5}{|c|}{ Model for DO } \\
\hline Average depth to groundwater & 0.15 & 0.55 & 0.30 & 0.001 \\
\hline \multicolumn{5}{|l|}{ Beta coefficients $($ constant $)=5.42$} \\
\hline \multicolumn{5}{|c|}{ Regression equation: $\mathrm{DO}=0.15$ (average depth to groundwater) +5.42} \\
\hline \multicolumn{5}{|c|}{ Model of turbidity } \\
\hline Discharge & 0.011 & 0.61 & 0.37 & 0.001 \\
\hline Average slope & -0.12 & & & \\
\hline \multicolumn{5}{|c|}{ Beta coefficients $($ constant $)=11.35$} \\
\hline \multicolumn{5}{|c|}{ Regression equation: Turbidity $=0.011($ discharge $)-0.12($ average slope $)+11.35$} \\
\hline \multicolumn{5}{|l|}{ Model of SC } \\
\hline Average slope & 29.6 & 0.75 & 0.57 & 0.001 \\
\hline Average depth to bedrock & 0.5 & & & \\
\hline \multicolumn{5}{|l|}{ Beta coefficients $($ constant $)=82.6$} \\
\hline \multicolumn{5}{|c|}{ Regression equation: $\mathrm{SC}=29.6$ (average slope) +0.5 (average depth to bedrock) +82.6} \\
\hline \multicolumn{5}{|l|}{ Model for nitrate } \\
\hline Pasture/hay & -0.02 & 0.43 & 0.18 & 0.053 \\
\hline Average slope & 0.14 & & & \\
\hline \multicolumn{5}{|l|}{ Beta coefficients $($ constant $)=3.03$} \\
\hline \multicolumn{5}{|c|}{ Regression equation: Nitrate $=0.014$ (average slope $)-0.02($ pasture/hay $)+3.03$} \\
\hline \multicolumn{5}{|l|}{ Model for phosphate } \\
\hline Average slope & 0.21 & 0.51 & 0.26 & 0.024 \\
\hline Urban & 0.08 & & & \\
\hline \multicolumn{5}{|l|}{ Beta coefficients $($ constant $)=3.47$} \\
\hline \multicolumn{5}{|c|}{ Regression equation: phosphate $=0.21$ (average slope $)+0.08$ (urban) +3.47} \\
\hline Model for biotic index & & & & \\
\hline Nitrate & 0.86 & 0.67 & 0.45 & 0.037 \\
\hline Precipitation & -0.02 & & & \\
\hline Beta coefficients $($ constant $)=5$. & & & & \\
\hline Regression equation: $\mathrm{BI}=0.86$ & -0.02 (precipitatic & & & \\
\hline
\end{tabular}

different times, there is a significantly better correlation between the WQI and the biotic index for the spring measurements than for the fall. This suggests that the water quality measurements acquired in the spring may be more indicative of the longer-term conditions for the streams in this study. 

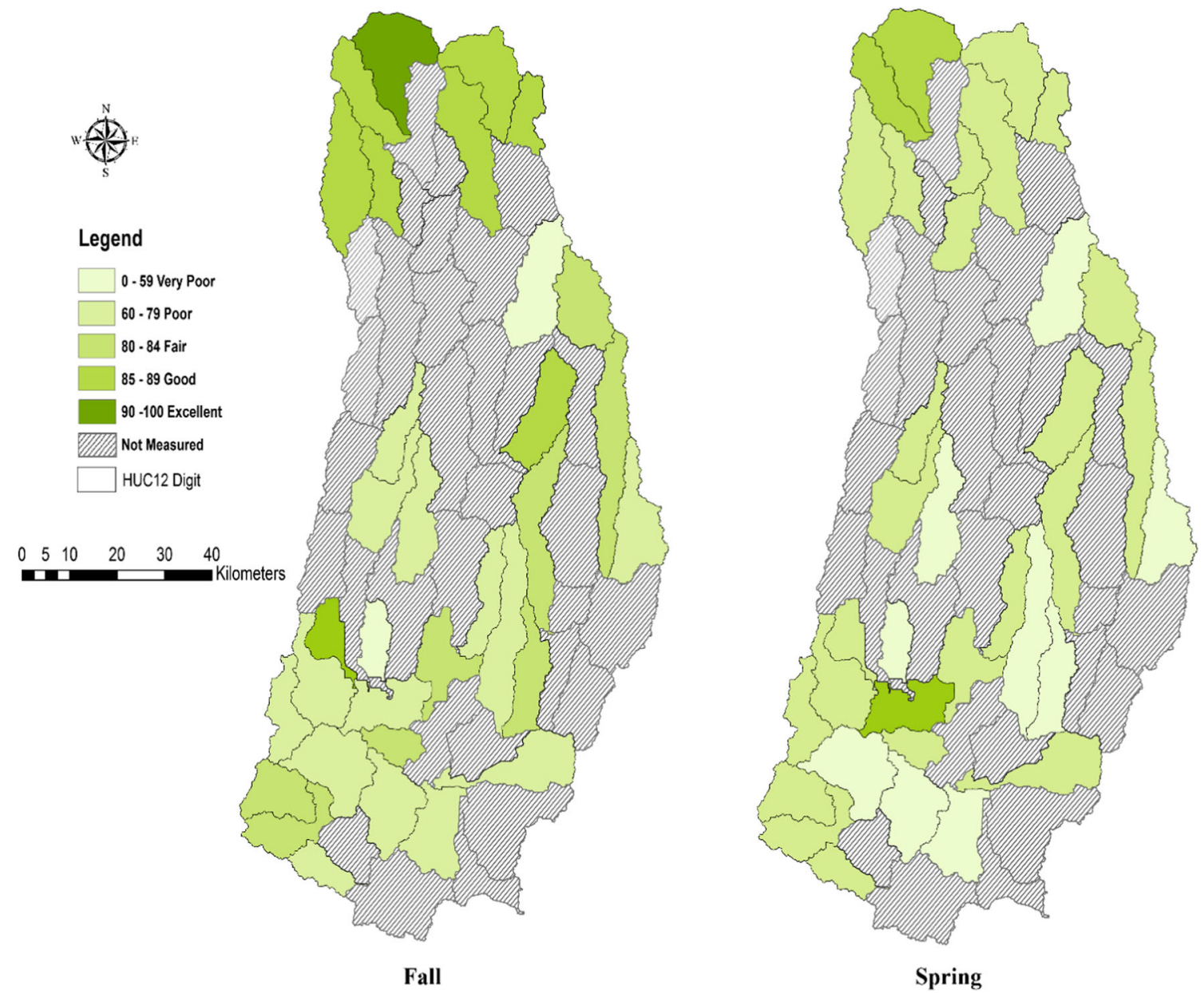

Fig. 5 Spatial distribution of the WQI for the study area during the fall and spring

\section{Principal component analysis}

Three principal components were obtained with eigenvalues $>1$, which accounted for $68.4 \%$ of the total variance in the data set in the fall and $69.2 \%$ in the spring. Figure 7 illustrates the first two principal components for each of these seasons, while Table 9 presents the strength of the correlation for individual parameters.

In the fall, the first principal component (PC1) correlated most highly with $\mathrm{P}$ and $\mathrm{N}$, and more weakly with SC. This component seems to be primarily associated with fertilizer runoff. The second principal component (PC2) correlated most highly with turbidity, E. coli, and BI. Turbidity may be affected by manure application but may also be strongly influenced by grazing livestock and associated streambed erosion. The correlations observed in PC2 imply that the biotic index could be more affected by livestock-related runoff (either directly from grazing livestock or from manure application to fields) than by the application of chemical fertilizers. In the spring, parameters were more similarly correlated with both $\mathrm{PC} 1$ and $\mathrm{PC} 2$, with fewer very strong correlations with either component than in the fall. $\mathrm{PC} 1$ was most correlated with $\mathrm{P}, \mathrm{pH}$, and $\mathrm{BI}$, while $\mathrm{PC} 2$ was most correlated with $\mathrm{SC}$ and N. Since the BI data were only acquired in the fall, the apparent correlation between BI and P in the spring (Fig. 7) may not be significant. However, the correlation between $\mathrm{N}$ and $E$. coli in the spring may indicate a common livestockbased source for these factors.

\section{Discussion}

The results of this study reveal that water quality parameters can vary significantly with season and may reflect recent land use, such as fertilizer application. Many of the results followed expected patterns; DO and turbidity are both higher when discharge is larger (i.e., in the spring, in this study). SC was lower during the spring, perhaps due to dilution. $P$-values were higher in the fall. This can be explained by higher discharge in the spring even though fertilizers are applied in approximately equal amounts in the fall and spring. $\mathrm{N}$ and $E$. coli are significantly higher in the spring, when more nitrogen-based fertilizer is applied and when more manure may also be applied. 
Fig. 6 Comparison between the water quality index (WQI) and biotic index (BI). a Fall. b Spring (a)

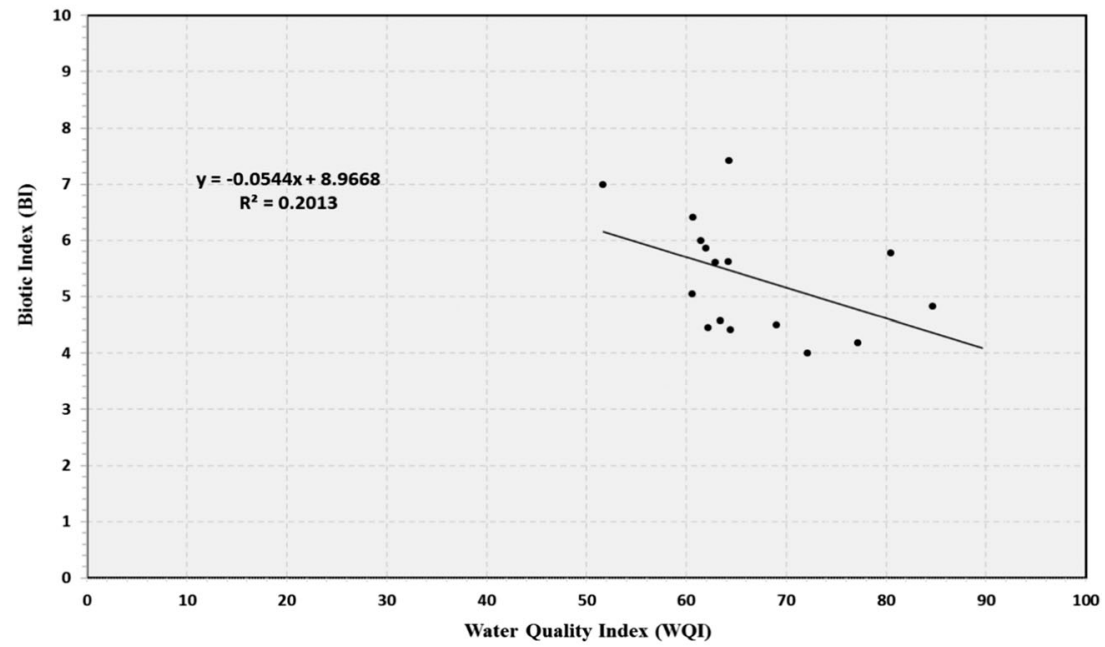

(b)

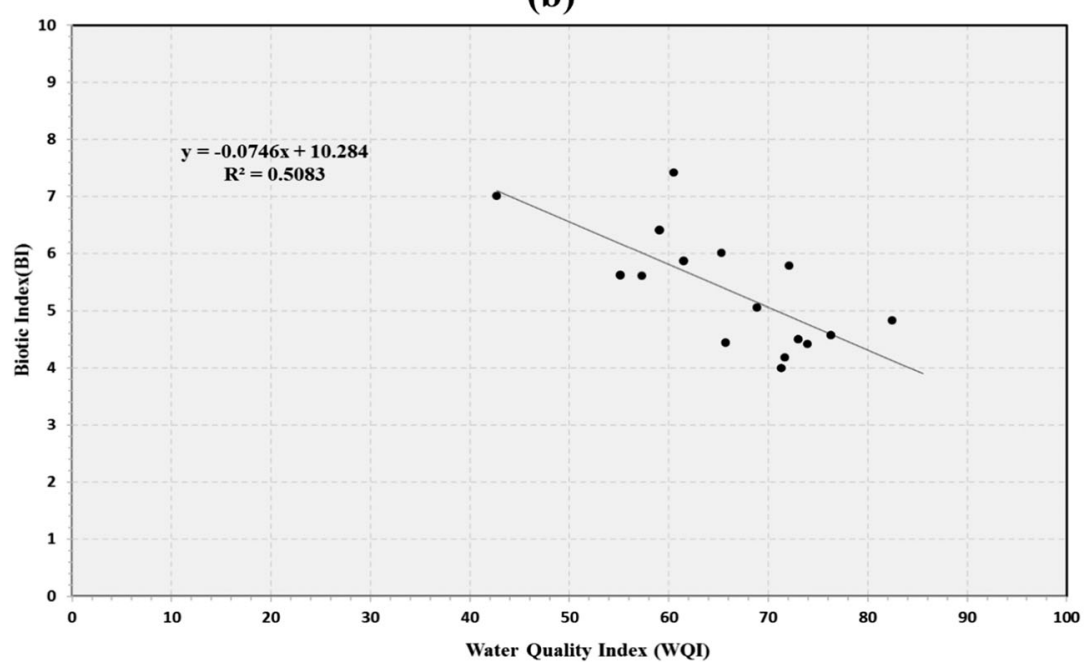

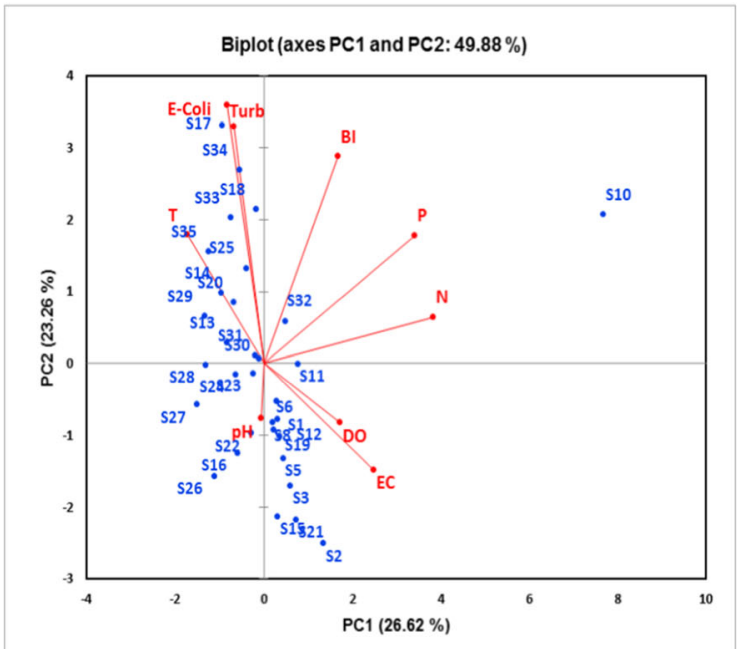

Fall

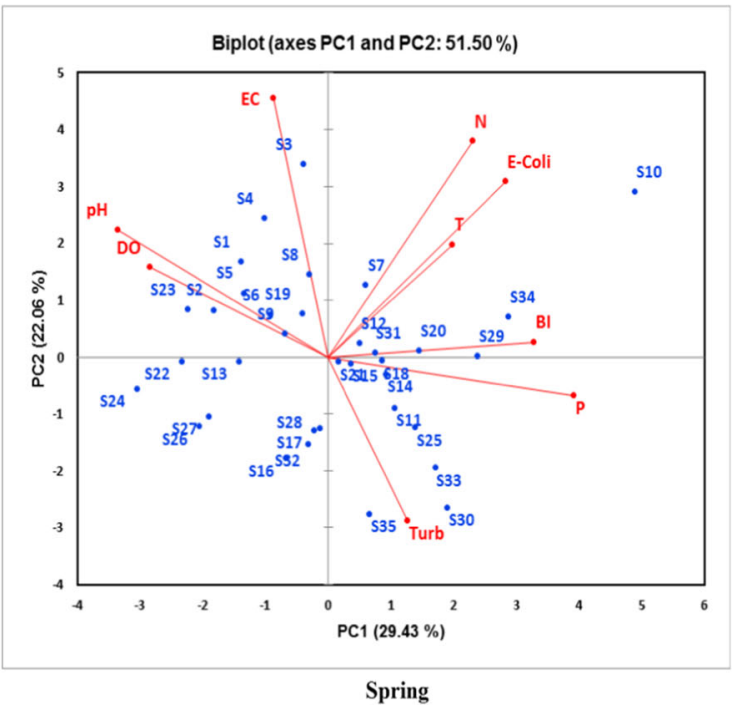

Spring

Fig. 7 PCA biplots of water quality indicators for fall and spring based on the first two PCs 
Table 9 Factor loadings values of water quality indicators for fall and spring

\begin{tabular}{|c|c|c|c|c|c|c|}
\hline & \multicolumn{3}{|l|}{ Fall } & \multicolumn{3}{|l|}{ Spring } \\
\hline & $\mathrm{PC} 1$ & $\mathrm{PC} 2$ & PC3 & $\mathrm{PC} 1$ & $\mathrm{PC} 2$ & PC3 \\
\hline \multicolumn{7}{|l|}{ Parameter } \\
\hline $\mathrm{T}$ & -0.411 & 0.397 & -0.646 & 0.400 & 0.346 & 0.693 \\
\hline $\mathrm{pH}$ & -0.012 & -0.171 & 0.465 & -0.678 & 0.393 & -0.313 \\
\hline DO & 0.411 & -0.185 & 0.727 & -0.574 & 0.276 & -0.342 \\
\hline $\mathrm{EC}$ & 0.591 & -0.330 & -0.431 & -0.176 & 0.796 & 0.507 \\
\hline Turbidity & -0.195 & 0.800 & 0.311 & 0.255 & -0.503 & -0.302 \\
\hline $\mathrm{P}$ & 0.810 & 0.396 & -0.201 & 0.790 & -0.117 & -0.137 \\
\hline $\mathrm{N}$ & 0.912 & 0.142 & -0.246 & 0.465 & 0.664 & -0.476 \\
\hline E. coli & -0.159 & 0.732 & -0.038 & 0.571 & 0.540 & -0.529 \\
\hline BI & 0.398 & 0.641 & 0.346 & 0.662 & 0.045 & 0.169 \\
\hline Eigenvalue & 2.396 & 2.094 & 1.668 & 2.649 & 1.986 & 1.596 \\
\hline Total variance $(\%)$ & 26.61 & 23.26 & 18.52 & 29.43 & 22.06 & 17.73 \\
\hline Cumulative variance (\%) & 26.61 & 49.88 & 68.41 & 29.43 & 51.49 & 69.23 \\
\hline
\end{tabular}

Compared to the literature, our study found similar results in its correlations of water quality with land use, geologic, or topographic parameters. For example, Tong and Chen (2002) studied correlations between land use and water quality parameters in watersheds in Ohio. They used data available from the US Environmental Protection Agency (USEPA) averaged over an 8t-year period and found that nitrogen, phosphorus, and fecal coliform were all positively correlated with both agricultural and urban land use. Similarly, our research found that these water quality parameters were correlated with pasture/hay land use, and E. coli and $\mathrm{P}$ were also correlated with the percentage of urban land. During the spring, cultivated crops were also significant for $\mathrm{N}$. The correlation analysis (Spearman's rank) performed by Tong and Chen (2002) showed that the correlations between each of these water quality parameters and urban land use was greater than the correlation with agricultural land use. Even though the percent of urban land in our study was small, our results also established that the percent of urban land was significant, although not always more significant than agricultural land use. The correlation factors (i.e., Pearson's correlation coefficient) in our investigation were generally higher than those observed by Tong and Chen (2002), possibly because we collected data for a relatively short time, whereas their data over a longer time span.

Galbraith and Burns (2006) focused on the impact of land modification on water quality in non-flowing water bodies (e.g., lakes, wetlands, estuaries, etc.) in southern New Zealand. They found that the conversion of native grasslands to pasture increased nutrient concentrations and turbidity. The Lower Grand study also showed that pasture/hay land use was highly correlated to nutrient concentrations and turbidity as well as to E. coli.
The results of this study were less similar to research conducted in the eastern USA, which has a very different physiography. Potter et al. (2005) considered the impact of land use as well as of topographic and geologic factors on benthic macroinvertebrates in North Carolina, and they found that forest was the land use variable that correlated most closely with macroinvertebrate health, while watershed shape was the second most important variable. However, we found that neither of these variables showed a high correlation with macroinvertebrate health, possibly because we studied primarily agricultural watersheds, not those what were heavily forested. Also, our study correlated chemical water quality parameters with macroinvertebrate health, with nutrients and turbidity being highly correlated to the biotic index.

On the east coast, Schoonover and Lockaby (2006) studied the impact of land cover in 18 watersheds in western Georgia. The watersheds in their study were much more urbanized than the Lower Grand River watersheds, and row crops were rare. Most watersheds in their study area were dominated by a single land cover class (i.e., unmanaged forest, managed forest, pasture, developing, or urban). They found that more urbanized watersheds typically had higher nutrients and $E$. coli than less urbanized watersheds. In the Lower Grand watershed, the percentage of land classified as urban is small, but urban land use still occurred as a factor that correlated significantly with several water quality parameters. This suggests that runoff from developed land, septic tanks, or municipal sewage may significantly impact water quality even in areas that are predominantly rural. Schoonover and Lockaby's (2006) work also had a temporal component. They found that nutrient concentrations were higher during storm flow than during baseflow conditions. In the Lower Grand study, nutrient concentrations seemed to be more influenced by the timing 
of fertilizer application. As such, concentrations of $\mathrm{N}$ were significantly higher in the spring (when more nitrogen fertilizer is applied) than in the fall. $P$ concentrations were higher in the fall, even though $\mathrm{P}$ fertilizer is applied in approximately equal amounts in the spring and fall.

PCA analysis demonstrated significant seasonal variations in PC1 and PC2 factors, as did other studies (Ouyang et al. 2006; Garizi et al. 2011). Several of the factors that influenced variability in the fall were the same as those observed by other researchers. Ouyang et al. (2006) acquired data in the fall and spring along the lower St. John's River in Florida, and they found that the most influential parameters for PC1 were N, P, and EC (related to SC) (positively correlated) and organic carbon (negatively correlated). In another study along the Nakdong River, Jung et al. (2016) discovered that PC1 was influenced by N, P, EC, organic carbon, and chemical oxygen demand. In the Lower Grand River, the fall PC1 was most influenced by $\mathrm{N}, \mathrm{P}$, and $\mathrm{SC}$ (positively correlated). In the spring, Ouyang et al. (2006) found that PC1 was most influenced by color, organic carbon (positively correlated) as well as alkalinity and SC (negatively correlated), while our study found that SC was weakly negative correlated with PC1 but strongly and positively correlated with PC2 in the spring.

\section{Conclusions}

Basic water quality measurements were acquired in 35 primarily agricultural watersheds during the fall and following spring. These measurements were used to calculate the biotic index and water quality index and were correlated with a variety of geologic, topographic, and LULC parameters. Pairwise comparison of the data acquired during the fall and spring showed that all water quality parameters were statistically different data sets with $p<0.02$ for all parameters, which suggests that the timing of water quality sampling is critical. Simple regression analysis of all variables revealed that correlations between independent variables and water quality indicators fluctuated with the season but that the "pasture/hay" LULC category (which includes livestock grazing) was statistically significant for several water quality indicators for both sampling campaigns. The percentage of land used for cultivated crops was only significant in the spring, when more fertilizer is applied. The amount of precipitation in the 2 weeks preceding data collection was also significant for some water quality parameters. The variation between seasons as well as the significance of precipitation to the correlations again implies that the timing of sampling campaigns may influence the correlations. Geologic parameters, such as depth to bedrock, depth to water table, slope, and soil type, were also significantly correlated to water quality parameters. Stepwise regression of independent variables and water quality indicators showed that different relationships were developed in the fall and spring. However, many of the independent variables within the stepwise regression relationships were the same for both seasons, indicating that some geologic or LULC parameters seem to consistently predict water quality. In the predictive relationships, topographic and geologic parameters occurred with the same or greater frequency as LULC parameters. Comparison of the water quality index with the biotic index demonstrated that these two indexes were best correlated during the spring, implying that the lower water quality conditions observed in the spring might be more representative of the longerterm water quality conditions in these watersheds. The correlation of turbidity, E. coli, and BI in the PCA analysis suggests that livestock grazing may adversely affect water quality in this watershed. PCA analysis also revealed that $\mathrm{N}, \mathrm{P}$, and $\mathrm{SC}$ contribute greatly to the observed water quality variability.

This study produced several practical implications: (1) sampling time, including both season and time since precipitation, may significantly impact correlations between water quality and LULC or geologic factors. Thus, timing should be a key aspect of the experimental design for field campaigns. (2) Both LULC and geologic/topographic variables are necessary to predict water quality indicators, so proposed best management practices to improve water quality should be undertaken with strong consideration of the geologic and topographic conditions of each site. Promoting best management practices in those watersheds that are most likely to be impaired (based upon geologic or topographic parameters) could help maximize the environmental benefit, with the least outlay of financial resources. (3) Although stepwise regression equations between water quality indicators and independent variables changed with the season, some independent variables were valuable predictors of water quality regardless of the season. This suggests that it may be possible to partially predict water quality indicators based on other factors, such as topographic, geologic, and LULC information. Predictive relationships cannot be used to provide specific values for water quality parameters but may be helpful for targeting sampling campaigns in streams most likely to experience impairment. This could create more efficient regulatory monitoring and improve resource allocation for water management. (4) The biotic index correlated most with parameters often associated with agriculture or urban runoff (i.e., N, P, turbidity) and was only weakly correlated with the WQI, calculated using Cude's (2001) generally accepted method. This implies that macroinvertebrate assessment could help to distinguish LULC inputs independently from physicochemical water parameters, and that other methods of calculating the WQI might be needed to better predict biological responses based on physicochemical properties. 
Acknowledgments The authors would like to express our appreciation to the students in the Missouri University of Science and Technology Geological Engineering Department who helped with fieldwork: Majid Mohamod, Denise Mathews, Taylor Steffen, and Christina Sehrt. The first author is grateful to the Ministry of Higher Education and Scientific Research and the Ministry of Water Resources in Iraq for their support.

Open Access This article is distributed under the terms of the Creative Commons Attribution 4.0 International License (http:// creativecommons.org/licenses/by/4.0/), which permits unrestricted use, distribution, and reproduction in any medium, provided you give appropriate credit to the original author(s) and the source, provide a link to the Creative Commons license, and indicate if changes were made.

\section{References}

Ahearn D, Sheibley R, Dahlgren R, Anderson M, Johnson J, Tate K (2005) Land use and land cover influence on water quality in the last free-flowing river draining the western Sierra Nevada, California. J Hydrol 313(3-4):234-247. https://doi.org/10.1016/j. jhydrol.2005.02.038

Alberti M, Booth D, Hill K, Coburn B, Avolio C, Coe S, Spriandelli D (2007) The impact of urban patterns on aquatic ecosystems: an empirical analysis in Puget lowland sectioned-basins. Landsc Urban Plan 80:345-361

Bu H, Tan X, Li S, Zhang Q (2010) Temporal and spatial variations of water quality in the Jinshui River of the south Qinling Mts., China. Ecotoxicol Environ Saf 73(5):907-913. https://doi.org/10.1016/j. ecoenv.2009.11.007

Buss DF, Vitorino AS (2010) Rapid bioassessment protocols using benthic macroinvertebrates in Brazil: evaluation of taxonomic sufficiency. J N Am Benthol Soc 29(2):562-571. https://doi.org/10.1899/09095.1

Chen W, He B, Nover D, Duan W, Luo C, Zhao K, Chen W (2017) Spatiotemporal patterns and source attribution of nitrogen pollution in a typical headwater agricultural watershed in southeastern China. Environ Sci Pollut Res 25(3):2756-2773. https://doi.org/10.1007/ s11356-017-0685-8

Cruzeiro C, Pardal MÂ, Rocha E, Rocha MJ (2015) Occurrence and seasonal loads of pesticides in surface water and suspended particulate matter from a wetland of worldwide interest - the Ria Formosa Lagoon, Portugal. Environ Monit Assess 187(11):669. https://doi. org/10.1007/s10661-015-4824-8

Cude CG (2001) Oregon water quality index: a tool for evaluating water quality management effectiveness. JAWRA 37:125-137. https://doi. org/10.1111/j.1752-1688.2001.tb05480.x

Detroy MG, Skelton J (1983) Hydrology of area 38, western region, interior coal province, Iowa and Missouri. Water-Resources Investigations Open-File Report 82-1014, U.S. Dept. of the Interior, Geological Survey, Rolla, MO

Driscoll C, Whitall D, Aber J, Boyer E, Castro M, Cronan C (2003) Nitrogen pollution in the northeastern United States: sources, effects, and management options. BioScience 53(4):357. https:// doi.org/10.1641/0006-3568(2003)053[0357:npitnu]2.0.co;2

Exner-Kittridge M, Strauss P, Blöschl G, Eder A, Saracevic E, Zessner M (2016) The seasonal dynamics of the stream sources and input flow paths of water and nitrogen of an Austrian headwater agricultural catchment. Sci Total Environ 542:935-945. https://doi.org/10.1016/ j.scitotenv.2015.10.151

Fournier M, Echeverría-Sáenz S, Mena F, Arias-Andrés M, De la Cruz E, Ruepert C (2017) Risk assessment of agriculture impact on the Frío River watershed and Caño Negro Ramsar wetland, Costa Rica.
Environ Sci Pollut Res 25:13347-13359. https://doi.org/10.1007/ s11356-016-8353-y

Fulhage CD (2000) Land Application Considerations for Animal Manure. EQ 202. MU Guide. MU Extension, University of Missouri-Columbia

Galbraith LM, Burns CW (2006) Linking land-use, water body type and water quality in southern New Zealand. Landsc Ecol 22(2):231241. https://doi.org/10.1007/s10980-006-9018-x

Gann EE, Barks JH, Fuller DL (1973) Water resources of northwestern Missouri: U.S. Geological Survey Hydrologic Investigations Atlas HA-444, 4 sheets

Garizi AZ, Sheikh V, Sadoddin A (2011) Assessment of seasonal variations of chemical characteristics in surface water using multivariate statistical methods. Int J Environ Sci Technol 8(3):581-592. https:// doi.org/10.1007/bf03326244

Gezie A, Anteneh W, Dejen E, Mereta S (2017) Effects of humaninduced environmental changes on benthic macroinvertebrate assemblages of wetlands in Lake Tana Watershed, Northwest Ethiopia. Environ Monit Assess 189(4):152. https://doi.org/10. 1007/s10661-017-5853-2

Haidary A, Amiri BJ, Adamowski J, Fohrer N, Nakane K (2013) Assessing the impacts of four land use types on water quality of wetlands in Japan. Water Resour Manag 27(7):2217-2229

Hildebrandt A, Guillamón M, Lacorte S, Tauler R, Barceló D (2008) Impact of pesticides used in agriculture and vineyards to surface and groundwater quality (North Spain). Water Res 42(13):33153326. https://doi.org/10.1016/j.watres.2008.04.009

Hilsenhoff WL (1988) Rapid field assessment of organic pollution with a family-level biotic index. J N Am Benthol Soc 7(1):65-68. https:// doi.org/10.2307/1467832

Homer CG, Dewitz JA, Yang L, Jin S, Danielson P, Xian G, Coulston J, Herold ND, Wickham JD, Megown K (2015) Completion of the 2011 National Land Cover Database for the conterminous United States - representing a decade of land cover change information. Photogramm Eng Remote Sens 81(5):345-354

Huang Z, Han L, Zeng L, Xiao W, Tian Y (2015) Effects of land use patterns on stream water quality: a case study of a small-scale watershed in the Three Gorges Reservoir Area, China. Environ Sci Pollut Res 23(4):3943-3955. https://doi.org/10.1007/s11356-0155874-8

Huiliang W, Zening W, Caihong H, Xinzhong D (2015) Water and nonpoint source pollution estimation in the watershed with limited data availability based on hydrological simulation and regression model. Environ Sci Pollut Res 22(18):14095-14103. https://doi.org/10. 1007/s11356-015-4450-6

Jeznach LC, Hagemann M, Park M, Tobiason JE (2017) Proactive modeling of water quality impacts of extreme precipitation events in a drinking water reservoir. J Environ Manag 201:241-251. https:// doi.org/10.1016/j.jenvman.2017.06.047

Jung KY, Lee K, Im TH, Lee IJ, Kim S, Han K, Ahn JM (2016) Evaluation of water quality for the Nakdong River watershed using multivariate analysis. Environ Technol Innov 5:67-82. https://doi. org/10.1016/j.eti.2015.12.001

Kannel PR, Lee S, Lee Y, Kanel SR, Khan SP (2007) Application of water quality indices and dissolved oxygen as indicators for river water classification and urban impact assessment. Environ Monit Assess 132(1-3):93-110. https://doi.org/10.1007/s10661-0069505-1

Kato T, Kuroda H, Nakasone H (2009) Runoff characteristics of nutrients from an agricultural watershed with intensive livestock production. J Hydrol 368(1-4):79-87. https://doi.org/10.1016/j.jhydrol.2009.01. 028

Kaurish FW, Younos T (2007) Developing a standardized water quality index for evaluating surface water quality. J Am Water Resour Assoc 43(2):533-545. https://doi.org/10.1111/j.1752-1688.2007. 00042.x 
Koçer MA, Sevgili H (2014) Parameters selection for water quality index in the assessment of the environmental impacts of land-based trout farms. Ecol Indic 36:672-681. https://doi.org/10.1016/j.ecolind. 2013.09.034

Kourgialas NN, Karatzas GP, Koubouris GC (2017) A GIS policy approach for assessing the effect of fertilizers on the quality of drinking and irrigation water and wellhead protection zones (Crete, Greece). J Environ Manag 189:150-159. https://doi.org/10.1016/j.jenvman. 2016.12.038

Lai Y, Yang C, Hsieh C, Wu C, Kao C (2011) Evaluation of non-point source pollution and river water quality using a multimedia twomodel system. J Hydrol 409(3-4):583-595. https://doi.org/10. 1016/j.jhydrol.2011.08.040

Lenat DR (1993) A biotic index for the southeastern United States: derivation and list of tolerance values, with criteria for assigning waterquality ratings. J North Am Benthol Soc 12(3):279-290. https://doi. org/10.2307/1467463

Li Z, Luo C, Xi Q, Li H, Pan J, Zhou Q, Xiong Z (2015) Assessment of the AnnAGNPS model in simulating runoff and nutrients in a typical small watershed in the Taihu Lake basin, China. CATENA 133:349 361. https://doi.org/10.1016/j.catena.2015.06.007

Liang T, Wang S, Cao H, Zhang C, Li H et al (2008) Estimation of ammonia nitrogen load from nonpoint sources in the Xitiao River catchment, China. J Environ Sci 20(10):1195-1201

López-López E, Sedeño-Díaz JE (2014) Biological indicators of water quality: the role of fish and macroinvertebrates as indicators of water quality. Environ Indicators 643-661. https://doi.org/10.1007/97894-017-9499-2 37

Maillard P, Santos NA (2008) A spatial-statistical approach for modeling the effect of non-point source pollution on different water quality parameters in the Velhas river watershed - Brazil. J Environ Manag 86(1):158-170. https://doi.org/10.1016/j.jenvman.2006.12.009

MDNR (2003) Stream habitat assessment project procedure. Field Services Section-032, Environmental Services Program, Jefferson City $40 \mathrm{pp}$

MDNR (2014) The state of our Missouri waters-Lower Grand River Watershed. Missouri Department of Natural Resources Water Protection Program, Jefferson City

MDNR (2016) Missouri integrated water quality report and sections 303(d), 305(b), and 314. Missouri Department of Natural Resources Water Protection Program, Jefferson City

Mereta ST, Boets P, Meester LD, Goethals PL (2013) Development of a multimetric index based on benthic macroinvertebrates for the assessment of natural wetlands in Southwest Ethiopia. Ecol Indic 29: 510-521. https://doi.org/10.1016/j.ecolind.2013.01.026

Midwestern Regional Climate Center (2016) (1981-2010) Normal annual snowfall-Midwestern States. Retrieved from /cliwatch/ annual_snowfall_normals_8110.png

Missouri Agricultural Experiment Station (2014) University of MissouriColumbia, Missouri Fertilizer Tonnage Report. http://aes.missouri. edu/pfcs/fert/. Accessed 5 Jan 2018

Missouri Department of Natural Resources (MDNR) (1984) Missouri Water Quality Basin Plan, vol 3. Missouri Department of Natural Resources, Jefferson City

Missouri Spatial Data Information Service (MSDIS) (n.d.) Mizzou. Retrieved from https://missouri.edu. Accessed 21 Feb 2017

Mouri G, Takizawa S, Oki T (2011) Spatial and temporal variation in nutrient parameters in stream water in a rural-urban catchment, Shikoku, Japan: effects of land cover and human impact. J Environ Manag 92(7):1837-1848. https://doi.org/10.1016/j. jenvman.2011.03.005

Narasimhan B, Srinivasan R, Bednarz ST, Ernst MR, Allen PM (2010) A comprehensive modeling approach for reservoir water quality assessment and management due to point and nonpoint source pollution. Trans ASABE 53(5):1605-1617. https://doi.org/10.13031/ 2013.34908
National Oceanic and Atmospheric Administration (NOAA) (2017) Climate observation and monitoring. Retrieved from http://www. noaa.gov/climate.html. Accessed 5 Aug 2017

Olsen RL, Chappell RW, Loftis JC (2012) Water quality sample collection, data treatment and results presentation for principal components analysis - literature review and Illinois River watershed case study. Water Res 46(9):3110-3122. https://doi.org/10.1016/j.watres. 2012.03 .028

Ouyang Y, Nkedi-Kizza P, Wu Q, Shinde D, Huang C (2006) Assessment of seasonal variations in surface water quality. Water Res 40(20): 3800-3810. https://doi.org/10.1016/j.watres.2006.08.030

Paulsen SG, Mayio A, Peck DV, Stoddard JL, Tarquinio E, Holdsworth SM, Olsen AR (2008) Condition of stream ecosystems in the US: an overview of the first national assessment. J North Am Benthol Soc 27(4):812-821. https://doi.org/10.1899/08-098.1

Potter KM, Cubbage FW, Schaberg RH (2005) Multiple-scale landscape predictors of benthic macroinvertebrate community structure in North Carolina. Landsc Urban Plan 71(2-4):77-90. https://doi.org/ 10.1016/j.landurbplan.2004.02.001

Pratt B, Chang H (2012) Effects of land cover, topography, and built structure on seasonal water quality at multiple spatial scales. J Hazard Mater 209-210:48-58. https://doi.org/10.1016/j.jhazmat. 2011.12.068

Ramos MA, Bueno de Oliveira ES, Pião AC, Nalin de Oliveira Leite DA, De Franceschi de Angelis D (2016) Water quality index (WQI) of Jaguari and Atibaia Rivers in the region of Paulínia, São Paulo, Brazil. Environ Monit Assess 188(5):263. https://doi.org/10.1007/ s10661-016-5261-z

Rothenberger MB, Burkholder JM, Brownie C (2009) Long-term effects of changing land use practices on surface water quality in a coastal river and lagoonal estuary. Environ Manag 44(3):505-523. https:// doi.org/10.1007/s00267-009-9330-8

Sangchan W, Bannwarth M, Ingwersen J, Hugenschmidt C, Schwadorf K, Thavornyutikarn P, Streck T (2013) Monitoring and risk assessment of pesticides in a tropical river of an agricultural watershed in northern Thailand. Environ Monit Assess 186(2):1083-1099. https://doi.org/10.1007/s10661-013-3440-8

Sarver RJ (2005) Taxonomic levels for macroinvertebrate identifications. Missouri Department of Natural Resources, Air and Lands Protection Division, Environmental Services Program, Jefferson City, p 30 http://www.cpcb.ku.edu/datalibrary/assets/library/ techdocs/Taxlevels2005May.pdf. Accessed July 2009

Schoonover JE, Lockaby BG (2006) Land cover impacts on stream nutrients and fecal coliform in the lower Piedmont of West Georgia. J Hydrol 331(3-4):371-382. https://doi.org/10.1016/j.jhydrol.2006. 05.031

Shamshad A, Leow C, Ramlah A, Hussin W, Sanusi S (2008) Applications of AnnAGNPS model for soil loss estimation and nutrient loading for Malaysian conditions. Int J Appl Earth Obs Geoinf 10(3):239-252. https://doi.org/10.1016/j.jag.2007.10.006

Sharma D, Kansal A (2011) Water quality analysis of River Yamuna using water quality index in the national capital territory, India (2000-2009). Appl Water Sci 1(3-4):147-157. https://doi.org/10. 1007/s13201-011-0011-4

Tong ST, Chen W (2002) Modeling the relationship between land use and surface water quality. J Environ Manag 66(4):377-393. https://doi. org/10.1006/jema.2002.0593

U.S. Department of Agriculture, Soil Conservation Service (USDA-SCS) (1982) The land and water resources of the northern Missouri River tributaries basin - Iowa and Missouri

U.S. Geological Survey (2006) Collection of water samples (ver. 2.0): U.S. Geological Survey Techniques of Water-Resources Investigations, book 9, chap. A4, September 2006. http://pubs. water.usgs.gov/twri9A4/. Accessed 7/5/3016 
USEPA (2013) Aquatic life ambient water quality criteria for ammonia freshwater. EPA-822-R-13-001. U.S. Environmental Protection Agency, Office of Water, Office of Sci Technol, Washington, DC

USEPA (2016) Aquatic life ambient water quality criteria. EPA-820-R16-002, U.S. Environmental Protection Agency, Office of Water, Office of Sci Technol, Washington, DC

Van Ael E, De Cooman W, Blust R, Bervoets L (2015) Use of a macroinvertebrate based biotic index to estimate critical metal concentrations for good ecological water quality. Chemosphere 119:138-144. https://doi.org/10.1016/j.chemosphere.2014.06.001

Vandike JE (1995) Surface water resources of Missouri. Missouri Dept. of Natural Resources, Division of Geology and Land Survey, Rolla

Walters SP, Thebo AL, Boehm AB (2011) Impact of urbanization and agriculture on the occurrence of bacterial pathogens and stx genes in coastal waterbodies of Central California. Water Res 45(4):17521762. https://doi.org/10.1016/j.watres.2010.11.032

Wang X, Tan X (2017) Macroinvertebrate community in relation to water quality and riparian land use in a substropical mountain stream, China. Environ Sci Pollut Res 24(17):14682-14689. https://doi. org/10.1007/s11356-017-9042-1

Wilkison DH, Armstrong DJ (2015) Water-quality assessment of the Lower Grand River Basin, Missouri and Iowa, USA, in support of integrated conservation practices. River Res Appl 32(4):583-596. https://doi.org/10.1002/rra.2887

Xu M, Wang Z, Duan X, Pan B (2013) Effects of pollution on macroinvertebrates and water quality bio-assessment. Hydrobiologia 729(1): 247-259. https://doi.org/10.1007/s10750-013-1504-y

Yu X, Hawley-Howard J, Pitt A, Wang J, Baldwin R, Chow A (2015) Water quality of small seasonal wetlands in the Piedmont ecoregion, South Carolina, USA: effects of land use and hydrological connectivity. Water Res 73:98-108. https://doi.org/10.1016/j.watres.2015. 01.007

Zeinalzadeh K, Rezaei E (2017) Determining spatial and temporal changes of surface water quality using principal component analysis. J Hydrol Reg Stud 13:1-10. https://doi.org/10.1016/j.ejrh.2017.07. 002

Zhang W, Huang B (2014) Soil erosion evaluation in a rapidly urbanizing city (Shenzhen, China) and implementation of spatial land-use optimization. Environ Sci Pollut Res 22(6):4475-4490. https://doi.org/ 10.1007/s11356-014-3454-y

Zhu Q, Schmidt JP, Bryant RB (2012) Hot moments and hot spots of nutrient losses from a mixed land use watershed. J Hydrol 414-415: 393-404. https://doi.org/10.1016/j.jhydrol.2011.11.011 